\title{
암석효히지
}

Jour. Petrol. Soc. Korea Vol. 20, No. 4, p. 173 189, 2011

\author{
한반도 동부 울진 죽변-부구 지역 암맥군과 단열계의 \\ 상대연령과 지구조적 의미 \\ 김창민 ${ }^{1} \cdot$ 김종선 ${ }^{1} \cdot$ 송철우 ${ }^{1} \cdot$ 손 문 ${ }^{*} \cdot$ 최성자 ${ }^{2}$ \\ 1부산대학교 지질환경과학과, ${ }^{2}$ 한국지질자원연구원 국토지질연구본부
}

\section{Dyke Swarms and Fracture System and their Relative Chronology and Tectonic Implications in the Jukbyeon-Bugu Area, Uljin, East Korea}

\author{
Chang-Min Kim¹, Jong-Sun Kim ${ }^{1}$, Cheol Woo Song ${ }^{1}$, Moon Son ${ }^{1 *}$ and Sung-Ja Choi ${ }^{2}$ \\ ${ }^{1}$ Department of Geological Sciences, Pusan National University, Busan 609-735, Korea \\ ${ }^{2}$ Geological Research Division, Korea Institute of Geoscience and Mineral Resources, Daejeon 305-350, Korea
}

\begin{abstract}
요 약: 한반도 동부 울진 죽변-부구 지역 맥암과 단열의 기하와 운동학적 특성 그리고 횡절관계를 파악하고, 맥암의 암석기재와 지화학을 분석하였다. 총 144 암맥과 370 개 절리의 방향성과 횡절관계를 이용하여 암맥은 세 개의 염기성 암맥군(M-10, M-80, M-100)과 한 개의 산성 암맥군(AD)으로 구분하고 절리는 네 개의 절리 군(J-10, J-40, J-80, J-150)으로 분류하였다. 또한 J-150 절리들 중 최후기에 우수향으로 재활된 것들을 F-340R 로 분류하였다. 암석기재, 지화학 그리고 산상을 종합하면, M- 80 과 M- 100 은 동일한 마그마와 응력장 하에서 각각 기존 단열과 마그마압력에 의해 새로이 만들어진 수압파쇄단열을 통로로 주입되었다. 또한 연구지역 암 맥과 단열군은 $<\mathrm{J}-40, \mathrm{~J}-80, \mathrm{~J}-150>\rightarrow<\mathrm{M}-80(\mathrm{M}-100)>\rightarrow<\mathrm{AD}>\rightarrow<\mathrm{J}-10>\rightarrow<\mathrm{M}-10>\rightarrow<\mathrm{F}-340 \mathrm{R}>$ 순 서로 형성되었다. 그리고 M-80과 M- 100 은 $\mathrm{N} 10^{\circ} \mathrm{E}$ 그리고 M-10은 북서-남동의 최소수평응력장에서 지각이 신 장된 결과이다. 한편 기존 절대연령 연구결과와 종합하여 분석하면, 이번 연구에서 확인된 암맥과 단열군들 중 M-80, M-10 그리고 F-340R은 64-52 Ma, 에오세 올리고세 그리고 마이오세에 각각 만들어진 것으로 해 석된다.
\end{abstract}

핵심어: 암맥, 절리, 횡절관계, 상대연령, 최소수평응력

\begin{abstract}
Basic to acidic dykes and systematic joints are observed pervasively in the Jukbyeon-Bugu area, Uljin, east Korea. In order to classify the dykes and joints and to determine the relative chronology, their geometries, kinematics, and cross-cutting relationships, and the petrography and geochemistry of dykes are synthetically analyzed. Based on the orientations and cross-cutting relationships of 144 dykes (137 basic and 7 acidic dykes) and 370 systematic joints, three basic dike swarms (M-10, M-80, and M-100), one acidic dyke group (AD), and four joint sets (J-10, J-40, J-80, and J-150) are classified. Some of the J-150 joints reactivated as dextral strike-slip fault are recognized in the field and named as F-340R. According to petrographic, geochemical, and occurrence features in the field, M-80 and M-100 dykes have originated from a co-magma and intruded under the same stress field, even though they have intruded through different passages, preexisting fractures and new fractures created by magmatic pressure, respectively. And the relative chronology of dyke swarms and joint sets in the study area is determined as follows : $<\mathrm{J}-40$, $\mathrm{J}-80, \mathrm{~J}-150>\rightarrow<\mathrm{M}-80(\mathrm{M}-100)>\rightarrow<\mathrm{AD}>\rightarrow<\mathrm{J}-10>\rightarrow<\mathrm{M}-10>\rightarrow<\mathrm{F}-340 \mathrm{R}>$. And the M-80 (M-100) and M-10 dyke swarms intruded under NNE-SSW and NW-SE trending horizontal minimum stress fields, respectively. According to a synthesis of the results of the previous and this studies, the M-80, M-10, and F-340R are interpreted to have been formed about 64-52 Ma, Eocene Oligocene, and Miocene, respectively.

Key words: dyke, joint, cross-cutting relationship, relative chronology, horizontal minimum stress
\end{abstract}

*Corresponding author

Tel: $051-510-2248$

E-mail: moonson@pusan.ac.kr 


\section{서 론}

2011년 3월의 일본 동북부 대지진과 지진해일로 인 한 원전사고는 원자력시설물 주변에서 발생한 지진이 얼마나 인간에게 위험한지를 여실히 보여주었다. 1980 년대 이후로 계기, 역사 그리고 고지진에 대한 자세 한 연구가 수행됨에 따라 한반도도 지진의 안전지대
가 아니라 10 15년 주기로 리히터 규모 5 이상의 지진이 발생하며, 최대 규모 약 6.7의 지진도 발생한 것으로 보고되어 있다(Lee and Yang, 2006; 이기화, 2010). 따라서 우리나라도 국가 지진재해대응체제를 구축하고 주요 시설물의 부지확보, 설계 그리고 유지 관리를 효율화하기 위해서는 지진재해도 작성이 필요 하며, 이를 위해서는 지진의 발생원이 되는 단층의

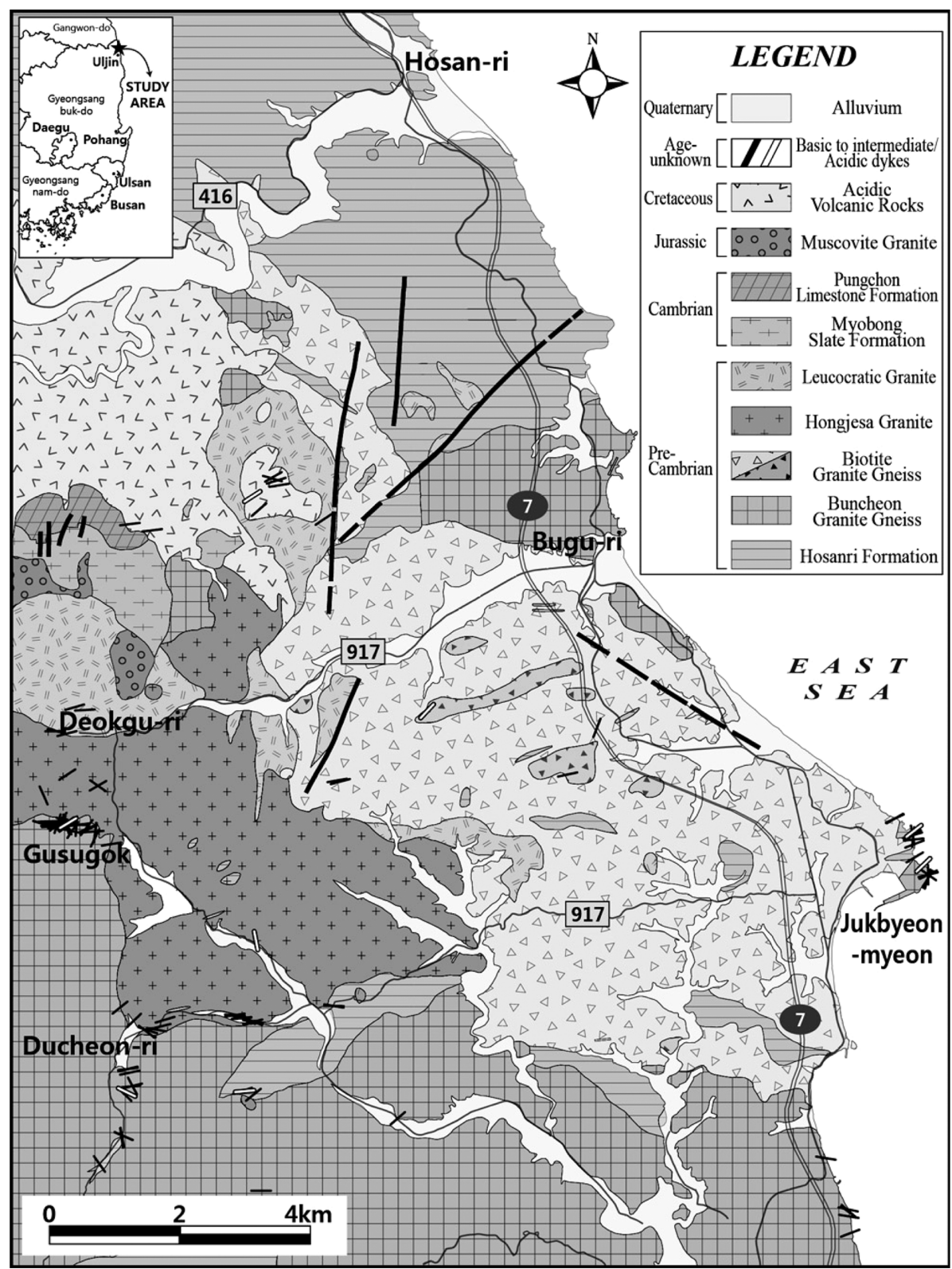

Fig. 1. Geological and dyke distribution maps of the Jukbyeon-Bugu area (modified from Lee et al., 1993). 
분포, 기하, 운동학적 특성을 비롯한 주요 단열계에 대한 상세한 연구가 우선적으로 필요하다. 특히 동해 안은 양산단층과 울산단층과 같은 대규모 단층과 더 불어 활동성단층들의 존재가 보고되어 있어 보다 상 세한 단열계 연구가 요구된다.

원자력시설물이 위치하는 경상북도 울진군 죽변-부 구 일대에는 일정한 방향성을 가지는 산성과 염기성 의 암맥들이 흔히 관찰된다(Fig. 1). 일반적으로 암맥 은 정치기구(emplacement mechanism)에 따라 크게 두 가지로 분류될 수 있는데, 지각이 신장되면서 신 장성 단열을 따라 마그마가 주입되는 수동형 관입 (passive injection)과 마그마 압력에 의한 수압단열작 용(hydraulic fracturing)의 결과인 강제형 관입(forceful injection)으로 나눌 수 있다(Price and Cosgrove, 1990; 김진섭 외, 2002; 손문 외, 2007). 이러한 암 맥들의 암석기재와 지화학적 특성, 관입 방향과 연령, 정치기구 그리고 주변 단열들과의 상호 횡절관계 등 은 광역 혹은 지역적인 고응력장과 지각변형사를 해 석하고 지구조적 의미를 밝히는 하나의 유용한 수단 으로 사용될 수 있다(Speight and Mitchell, 1979; Bussell, 1989; Glazner et al., 1999; Borradaile, 2001; 김진섭 외, 2002; Mayborn and Lesher, 2004; 김종 선 외, 2005; Gall et al., 2005; Khan et al., 2006; 손문 외, 2007; 양석준 외, 2008, 2010; 안성호 외, 2010). 특히 체계적으로 나타나는 암맥군과 주변 단 열들간의 횡절관계를 이용하여 이들의 상대연령과 함 께 지각변형사건의 순서를 파악하는 연구는 오늘날 지진발생과 밀접히 관련된 최후기 지각변형사건을 구 분하고 그 특성을 파악하는데 기여할 것이다.

이번 연구는 울진 신원전 부지 반경 약 $8 \mathrm{~km}$ 에 해당하는 경상북도 울진군 죽변-부구 지역(Fig. 1)을 대상으로 상세한 야외조사를 실시하여 암맥들의 기하 와 암상을 기재하고 대표 암석을 대상으로 경하관찰 과 지화학 분석을 실시하여 암맥군을 분류하였으며, 주변의 각종 취성변형요소인 단층, 전단단열, 신장성 절리의 기하 및 운동학적 특징을 기재하고 이들의 횡 절관계를 이용하여 상대연령을 밝히고자 하였다. 이 를 통하여 연구지역의 암맥 분포와 이와 관련된 각종 단열과의 상호 관계를 고려한 단열계의 특성과 원인 이 되는 고응력을 해석함으로서, 연구지역 지각변형 과 단열계 발달사를 규명하는데 토대를 마련하고자 하였다.

\section{지질개요}

행정구역상으로 경상북도 울진군 죽변면과 북면일 대에 해당되는 연구지역은 한반도의 지체구조구 상으 로 영남육괴 북동부 말단에 위치하며 선캠브리아의 변성퇴적암인 호산리층과 이를 관입한 변성화강암류 (분천화강편마암, 흑운모화강편마암, 홍제사화강암, 우 백질화강암), 캄브리아기의 퇴적암류(묘봉층, 풍촌층), 쥬라기 백운모 화강암, 그리고 백악기의 산성 화산암 류로 구성된다(이종혁 외, 1993; 정창식 외, 2001, 2004; 강지훈 외, 2006). 또한 백악기 이후에 이들을 관입하고 있는 다수의 산성과 중성 염기성의 암맥들 이 발달한다(Fig. 1).

연구지역의 암맥들은 변성된 흔적이 없으며 백악기 산성 화산암류를 관입하고 있어 백악기 말에서 이후 신생대 동안의 마그마 활동의 결과로 판단되며, 이들 암맥은 육안판별 시 산성에서 염기성까지 조성이 다 양하게 나타난다. 암맥들은 선캠브리아 분천화강편마 암이 분포하는 죽변항과 두천리 남부 그리고 선캠브 리아 분천화강편마암과 홍제사화강암의 경계지역에 해당하는 구수곡 계곡과 두천리 북구에서 집중적인 분포를 보인다. 또한 모암이 선캠브리아의 우백질화 강암으로 이루어진 덕구온천 서쪽 계곡부와 백악기의 산성 화산암류로 이루어진 북면 일대에서도 다수의 암맥들이 관찰된다(Fig. 1).

\section{절리군과 암맥군의 분류와 야외기재}

\section{암맥군의 분류와 야외산상}

연구지역의 암맥들은 야외에서 염기성에서 산성암 으로 추정되는 다양한 색깔을 보여준다. 이곳 암맥들 은 대부분 육안으로 정확한 성분을 구별하기 힘들만 큼 세립질 또는 유리질이기 때문에 색지수 그리고 육 안으로 관찰이 가능한 반정의 종류와 함량 정도를 근 거로 일차적으로 야외에서 중성 염기성 그리고 산성 암맥으로 구분하였다. 총 137 개의 중성 염기성 암맥 과 7개의 산성 암맥을 관찰하여(Fig. 2), 이들의 기하 와 야외산상이 기재되었다.

야외에서 관찰된 암맥들 상호간의 횡절관계 그리고 투영망과 장미도표에서 분석된 방향성을 이용하여 중 성 염기성 암맥들은 총 3 개의 암맥군 즉, $\mathrm{M}-10$ (주 관입방향이 $\mathrm{N} 10^{\circ} \mathrm{E}$ 내외인 암맥군), $\mathrm{M}-80$ (주 관입방 향이 $\mathrm{N} 80^{\circ} \mathrm{E}$ 내외인 암맥군), M-100 (주 관입방향이 


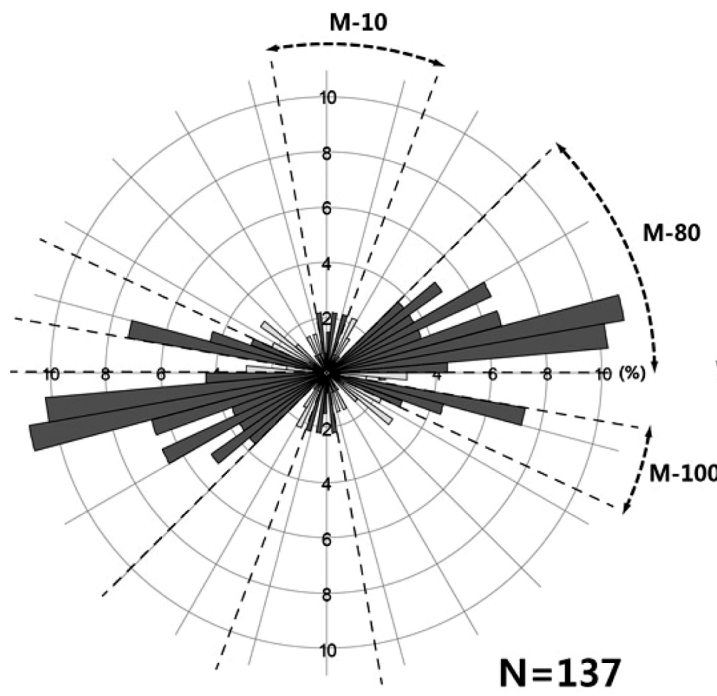

(A)

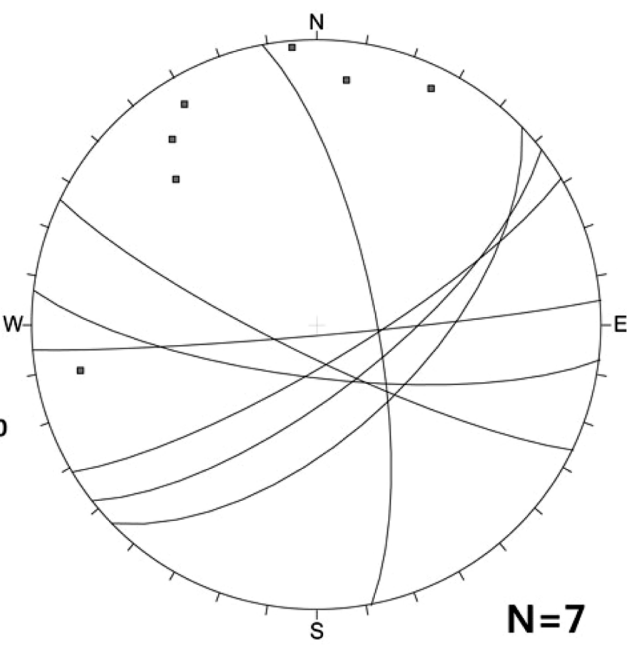

(B)

Fig. 2. (A) Rose diagram and (B) stereographic projection showing the attitudes of mafic to intermediate dykes and of acidic dykes, respectively. The mafic to intermediate dykes are classified into three groups, based on their orientations.

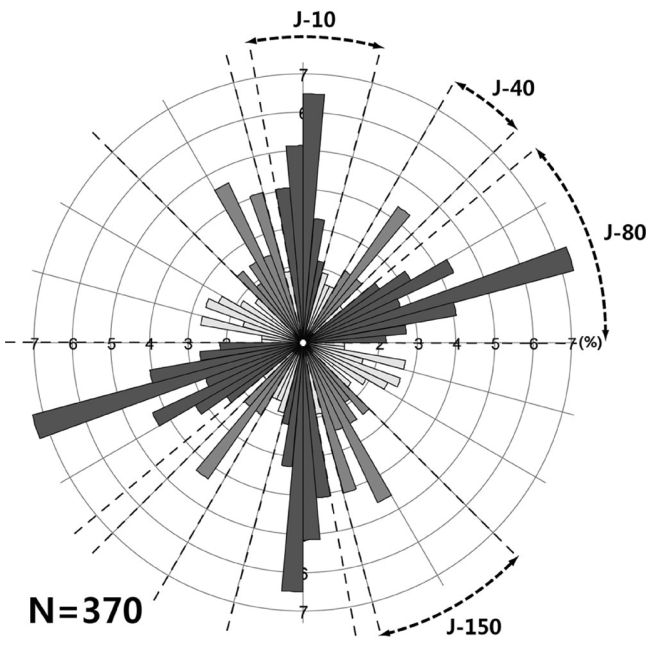

Fig. 3. Rose diagram showing the classification of joints based on their orientations.

$\mathrm{N} 80^{\circ} \mathrm{W}$ 내외인 암맥군)으로 나누었다(Fig. 1A). M80 암맥군이 연구지역에서 가장 흔히 산출되는데, 이 암맥들의 관입방향은 $\mathrm{N} 45^{\circ} \mathrm{E} \sim \mathrm{N} 90^{\circ} \mathrm{E}$ 로써 상대적으로 다양한 방향성을 보여주는 이유는 이들 암맥이 대부 분 기존 절리들을 이용하여 마그마가 주입되어 한 노 두에서도 지그재그 형태로 방향이 다양하게 변화되는 특성을 가지고 있기 때문이다(Fig. 4A). 한편, 이번
연구에서 관찰된 산성 암맥은 7매로 상대적으로 개체 수가 적어 모두를 묶어 하나의 암맥군(AD)으로 취급 하였다.

M-80 암맥군은 암회색 내지 암청색의 세립질 조직 을 보이고 있으며, 반정으로 사장석이 관찰된다. 이들 암맥은 죽변항, 북면, 덕구온천 서편 계곡, 구수곡 계 곡, 두천리 등의 지역에서 선캠브리아에서부터 백악 기 산성 화산암류까지 연구지역 모든 암석들 내에서 관찰된다(Fig. 1). 특징적으로 관입체 주변에 관입방 향과 조화롭게 발달하는 기존 단열들을 이용하며 관 입하여, 모암과의 관입접촉면이 명확한 판상으로 서 로 다른 방향의 직선들이 교차되는 지그재그 형태를 보인다. 일부 노두에서는 관입접촉면과 거의 수직한 방향으로 마그마의 주입 직후 냉각과정에서 만들어진 거의 남북 방향의 냉각절리(cooling joint)가 관찰된다 (Fig. 4A).

M-100 암맥군은 야외에서 M-80과 매우 유사한 조 직과 광물조성을 보이나 상대적으로 출현 빈도는 낮 다(Fig. 2A). 이 암맥들은 분천화강편마암과 홍제사화 강암이 분포하는 구수곡 계곡과 두천리 일대에서 주 로 관찰되는데, 특징적으로 관입체 주변에 관입방향 과 유사한 체계적인 단열계가 발달하지 않으며, 관입 면이 울퉁불퉁한 형태로 매우 불규칙하고, 한 노두에 서도 암맥의 관입 폭의 변화가 심하며, 수 $\mathrm{cm}$ 의 세 

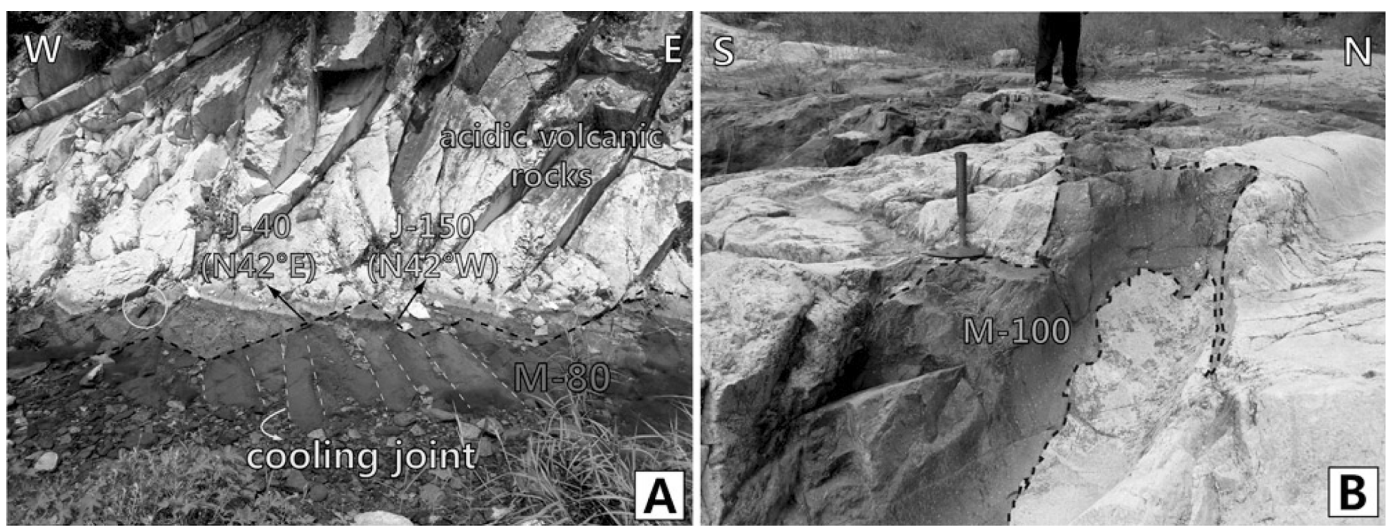

Fig. 4. Outcrop photographs showing two types of injections of the mafic to intermediate dykes, (A) M-80 dyke intruding through preexisting fractures and (B) M-100 dyke intruding into new fractures created by magmatic pressure.

맥으로 모암 내로 주입되다가 첨멸하는 양상도 관찰 된다(Fig. 4B). 이와 같은 M-100 암맥들은 높은 마 그마 압력에 의해 기반암이 수압파쇄되면서 마그마가 주입되는 강제형 관입의 결과임을 지시한다.

$\mathrm{M}-10$ 암맥군은 중성 염기성 암맥군들 중에 가장 출현빈도가 낮으나(Fig. 2A) 야외에서 다른 암맥군들 과 뚜렷한 횡절관계를 보이고 있어 독립적인 하나의 관입사건을 지시하는 암맥군으로 구분하였다. M-80 과 M-100에 비해 풍화와 변질이 심하게 진행되어 표 면이 특이하게 담황색을 띠고 있어 야외에서 쉽게 구 분되나, 파괴된 신선한 내부는 M-100 및 M-80과 유 사한 세립 내지 유리질 기질부에 $1 \mathrm{~mm}$ 내외의 장석 반정들이 관찰된다. 주로 죽변항 근처의 해안노두에 서 관찰되며, $\mathrm{M}-80$ 과 마찬가지로 관입체 주변에 관 입방향과 유사한 절리계가 발달하고 있고, 거의 직선 의 명확한 관입경계면을 보여주고 있어 기존 절리를 이용한 관입의 결과로 해석된다.

산성 암맥군인 $\mathrm{AD}$ 는 야외에서 중성 염기성 암맥 들과 확연히 구분되는 담황색 내지 유백색을 띠며 육 안으로 세립의 석영 입자들이 흔히 관찰되는 것으로 보아 유문암에 가깝다. 또한 상대적으로 높은 유문암 질 마그마의 점성에 의해 관입면과 거의 평행하게 발 달하는 유동띠(flow-bend, Raymond, 1995)와 함께 이에 따른 절리가 관찰된다. 암맥은 관입 폭이 $7 \sim 8 \mathrm{~m}$ 내외로서 $1 \sim 2 \mathrm{~m}$ 내외의 폭을 가지는 중성 염기성 암 맥들에 비해 큰 규모로 산출된다.

\section{절리군의 분류}

체계적인 절리계를 관찰할 수 있는 대표적인 노두
를 선택하여 총 370 개의 절리의 자세를 측정하였으 며, 이를 장미도표로 나타내면 연구지역의 절리들은 $\mathrm{J}-10$ (평균 방향 $\mathrm{N} 10^{\circ} \mathrm{E}$ ), $\mathrm{J}-40$ (평균 방향 $\mathrm{N} 40^{\circ} \mathrm{E}$ ), J80 (평균 방향 $\mathrm{N} 70^{\circ} \mathrm{E}$ ), $\mathrm{J}-150$ (평균 방향 $\mathrm{N} 30^{\circ} \mathrm{W}$ )의 총 4개 절리군으로 나누어진다(Fig. 3). J-80 절리군 은 평균 방향이 $\mathrm{N} 70^{\circ} \mathrm{E}$ 이나, 주로 $\mathrm{M}-80$ 암맥들의 관 입 통로가 되고 있어 J-80으로 명명하였다. 또한 장 미도표로는 나타낼 수 없으나, J-150 절리군에 속하 는 단열들 중 일부는 주향이동단층으로 재활되어 기 존 암맥들과 절리들을 절단하여 우수향으로 변위시키 고 있어 이를 F-340R 단층군으로 분류하였다.

절리의 출현빈도는 $\mathrm{J}-80, \mathrm{~J}-10, \mathrm{~J}-150, \mathrm{~J}-40$ 순으로 높게 나타나며, J-10과 J-80은 암맥군 중 각각 M- 10 , $\mathrm{M}-80$ 과 매우 유사한 방향성을 보여준다. 야외 관찰을 통해 볼 때, $\mathrm{M}-10$ 과 $\mathrm{M}-80$ 은 주로 각각 J-10과 J-80 을 통로로 이용하여 관입한 양상인 반면, M-100 암 맥군은 대부분 관입경계면이 매우 불규칙하고 대개 암맥 주변에 체계적인 절리군이 관찰되지 않는다.

\section{암맥군과 절리군들 간의 상대연령}

야외에서 다른 암맥군과의 횡절관계가 확인되지 못 한 M-100 암맥군을 제외하고, 암맥군과 절리군들 간 의 상대연령은 상호간의 횡절관계가 분명한 노두들을 이용하여 결정되었다. 이들 노두 중에 대표적인 노두 를 살펴보면(Fig. 5 와 6 ), 다음과 같이 암맥군과 절리 군들 사이의 횡절관계가 확인된다.

먼저 죽변항 부근 해안에서 암맥군과 절리군들의 상호 횡절관계를 잘 보여주는 UJ-8 노두의 스케치와 주요 사진들을 Fig. 5에 도시하였다. M-80 암맥들은 

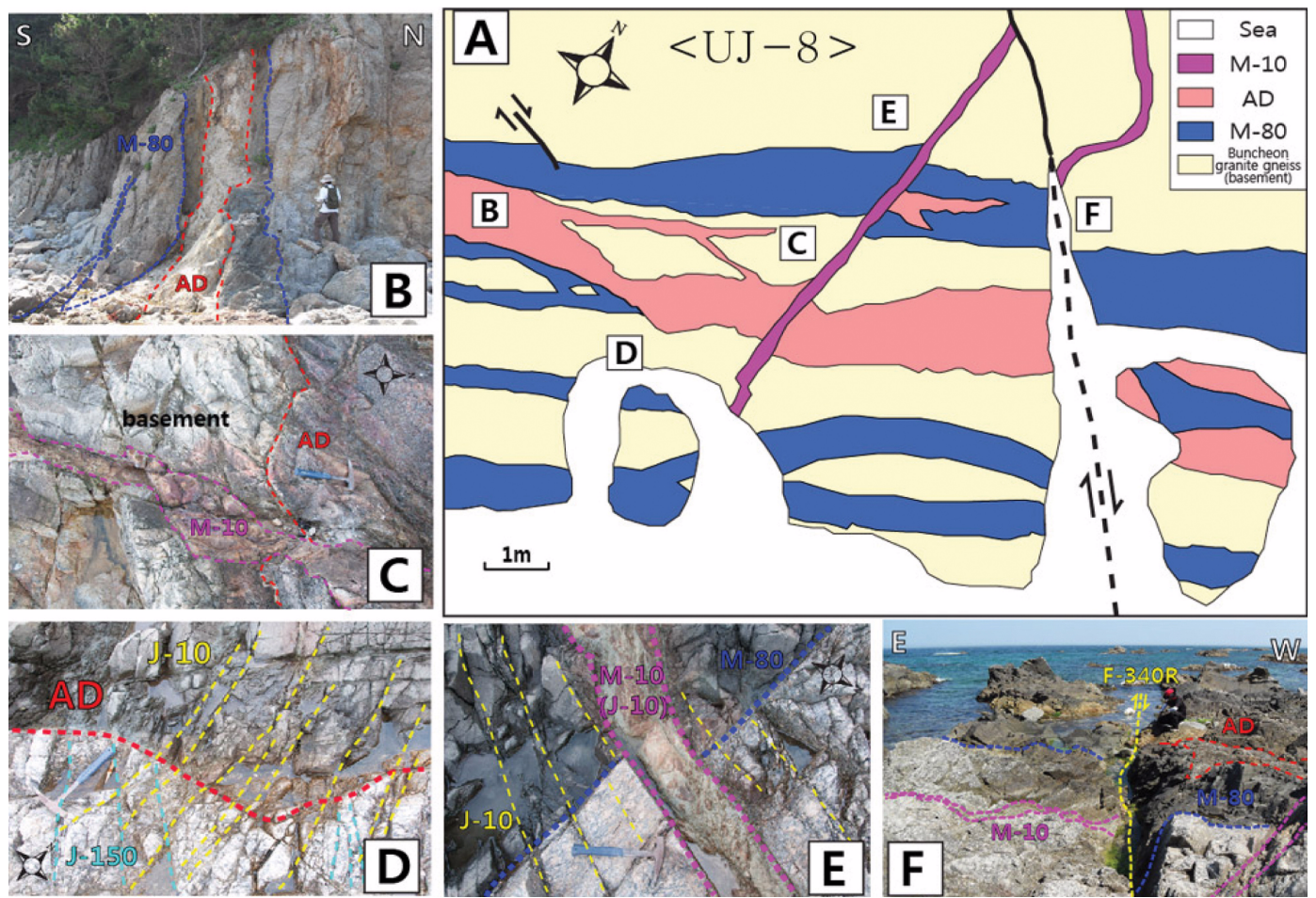

Fig. 5. Schematic outcrop sketch $(A)$ and outcrop photographs $(B \sim F)$ showing the relative chronologies among the dyke and joint groups.

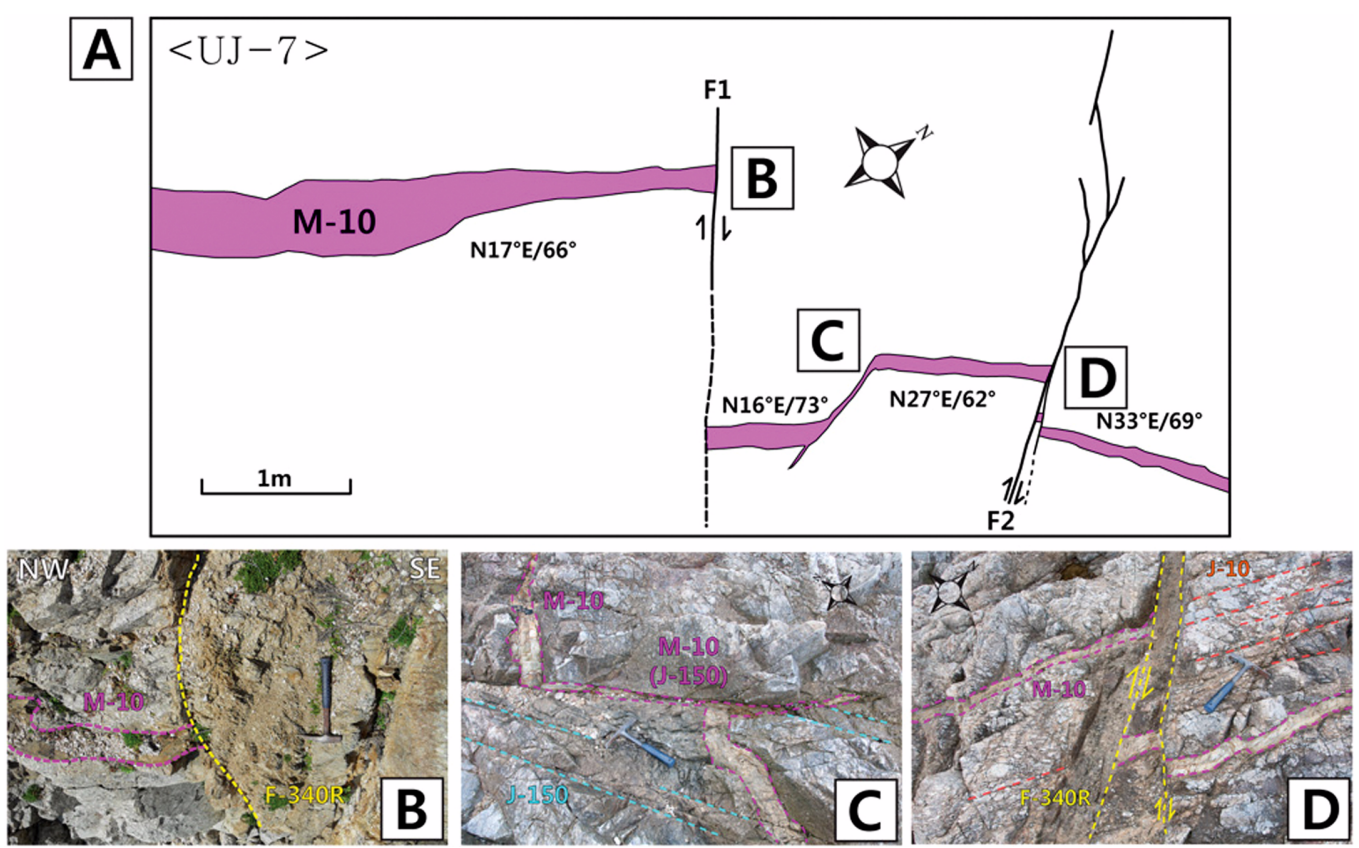

Fig. 6. Schematic outcrop sketch $(A)$ and outcrop photographs $(B \sim D)$ showing the relative chronologies among the dyke and joint groups. 
Table 1. Matrix analysis of relative chronology of the dyke and joint groups in the study area. Left first column and top rank indicate their arbitrary relative chronological order

\begin{tabular}{ccccccccccc}
\hline & $\mathrm{J}-40$ & $\mathrm{~J}-80$ & $\mathrm{~J}-150$ & $\mathrm{M}-80$ & $\mathrm{AD}$ & $\mathrm{J}-10$ & $\mathrm{M}-10$ & $\mathrm{~F}-340 \mathrm{R}$ & $\mathrm{M}-100$ \\
\hline $\mathrm{J}-40$ & & $?$ & $?$ & $\mathrm{Y}$ & $\mathrm{Y}$ & $?$ & $\mathrm{Y}$ & $?$ & $?$ \\
$\mathrm{~J}-80$ & $?$ & & $?$ & $\mathrm{Y}$ & $?$ & $?$ & $\mathrm{Y}$ & $?$ & $?$ \\
$\mathrm{~J}-150$ & $?$ & $?$ & & $\mathrm{Y}$ & $\mathrm{Y}$ & $?$ & $\mathrm{Y}$ & $?$ & $?$ \\
$\mathrm{M}-80$ & $\mathrm{O}$ & $\mathrm{O}$ & $\mathrm{O}$ & & $\mathrm{Y}$ & $\mathrm{Y}$ & $\mathrm{Y}$ & $\mathrm{Y}$ & $?$ \\
$\mathrm{AD}$ & $\mathrm{O}$ & $?$ & $\mathrm{O}$ & $\mathrm{O}$ & & $\mathrm{Y}$ & $\mathrm{Y}$ & $\mathrm{Y}$ & $?$ \\
$\mathrm{~J}-10$ & $?$ & $?$ & $?$ & $\mathrm{O}$ & $\mathrm{O}$ & & $\mathrm{Y}$ & $\mathrm{Y}$ & $?$ \\
$\mathrm{M}-10$ & $\mathrm{O}$ & $\mathrm{O}$ & $\mathrm{O}$ & $\mathrm{O}$ & $\mathrm{O}$ & $\mathrm{O}$ & $\mathrm{O}$ & $\mathrm{Y}$ & $?$ \\
$\mathrm{~F}-340 \mathrm{R}$ & $?$ & $?$ & $?$ & $\mathrm{O}$ & $\mathrm{O}$ & $\mathrm{O}$ & $\mathrm{O}$ & & $?$ \\
$\mathrm{M}-100$ & $?$ & $?$ & $?$ & $?$ & $?$ & $?$ & $?$ & $?$ & $?$ \\
※ Y $:$ Younger, O : Older & & & & & & & & &
\end{tabular}

지그재그 형태로 기존에 존재하고 있던 J-40, J-80, 그리고 $\mathrm{J}-150$ 의 절리들을 관입통로로 사용하여 마그 마가 주입되었으며(Fig. 4A와 7C), 이 암맥 내부에는 산성 암맥이 관입되어 있음이 관찰되었다(Fig. $5 \mathrm{~B}$ ). 그리고 산성 암맥은 $\mathrm{J}-150$ 을 절단하나 $\mathrm{J}-10$ 과 $\mathrm{M}-10$ 에 의해서 절단되며(Fig. $5 \mathrm{C}$ 와 $5 \mathrm{D}), \mathrm{M}-10$ 은 $\mathrm{M}-80$ 을 절단하고 $\mathrm{J}-10$ 의 절리들을 관입통로로 사용하여 관입하였다(Fig. 5E). 한편, F-340R은 M-80, $\mathrm{AD}$, $\mathrm{M}-10$ 암맥들과 다른 모든 절리군들을 우수향으로 변 위시키며 절단하고 있음이 관찰된다(Fig. $5 \mathrm{~F}$ ).

죽변항 인근 해안 노두에서 관찰된 또 다른 노두 UJ-7을 살펴보면(Fig. 6), J-10을 통로로 하여 관입한 M-10 암맥은 F-340R에 의해 절단되어 우수향으로 변위되어 있음이 관찰된다(Fig. 6B와 6D). 또한 $\mathrm{M}-$ 10 은 기존 절리인 J-150 내에도 세맥으로 분기되어 관입하다가 첨멸되는 양상이 관찰된다(Fig. 6C).

이상의 횡절관계들을 이용하여 행렬분석(matrix analysis)을 시도하면(Table 1), 횡절관계가 확인되지 못한 M-100을 제외하고 연구지역의 암맥군과 절리군 들의 상대연령은 $<\mathrm{J}-40, \mathrm{~J}-80, \mathrm{~J}-150>\rightarrow<\mathrm{M}-80>\rightarrow$ $<\mathrm{AD}>\rightarrow<\mathrm{J}-10>\rightarrow<\mathrm{M}-10>\rightarrow<\mathrm{F}-340 \mathrm{R}>$ 로 정리 할 수 있다.

\section{암맥군과 관계된 인장응력}

이론적으로 암맥은 최소수평응력 방향에 수직하게 지각이 신장하여 만들어진 인장 틈 내로 마그마가 주 입되어 만들어지는 것으로 알려져 있다(Anderson, 1951). 그러나 Tokarski(1990)는 이 이론이 보편적으 로 잘 사용되지 않는다고 주장하였는데, 그 이유로는 첫째, 야외에서 관찰된 다수의 암맥들이 관입통로로
사용한 기존절리의 방향이 관입 당시 작용된 최소수 평응력 방향과 수직하지 않은 방향일 확률이 높으며 (e.g. Bahar and Girod, 1983), 둘째, 암맥이 기존의 단층을 채우며 관입할 경우, 암맥정치시기에 전단응 력을 겪을 수도 있으며(Esher et al., 1976; Best, 1988), 셋째, 암맥이 형성되는 동안 다방향성의 인장 력(multidirectional extension)을 경험하는 경우(e.g. Gautneb, 1988) 등에 의해 암맥의 관입 방향은 최소 수평응력 방향과 항상 수직하지는 않다고 주장했다. 특히 첫 번째 경우와 같이 모암 내에 기존 절리들이 존재할 경우에는 이로 인해 암맥의 관입방향이 크게 좌우되며, 동일한 응력장 하에서도 기존 절리의 방향 성에 따라 지그재그와 같은 다양한 방향의 관입면을 가질 수 있다(e.g. Delaney et al., 1986; Bussell, 1989; Glazner et al., 1999; Gall et al., 2005; 양 석준 외, 2008). 또한 모암 내에 관입통로로 이용할 수 있는 기존 절리가 존재하지 않는 구간에는 마그마 의 압력에 의해 최소수평응력에 수직한 방향으로 일 종의 수압단열작용이 발생하여 전형적인 강제형 암맥 의 형태를 보이기도 한다. 그리고 기존 절리를 관입 의 통로로 이용한 암맥은 기존 절리의 방향이 최소수 평응력 방향과 수직일 때 폭이 가장 두꺼운 반면, 평 행할 때 관입 폭이 최소가 된다. 한편, 지그재그 형 태를 가지는 암맥의 경우에 관입면이 굴곡되는 부분 에서 암맥이 관입하기 이전에 서로 접하고 있었던 부 분을 구할 수 있다면, 마그마 관입으로 변화된 두 지 점을 연결한 방향을 측정하면 지각의 신장방향이 결 정되어 암맥이 형성될 당시의 최소수평응력방항을 비 교적 정확히 알아낼 수 있음이 보고되어 있다 (Delaney et al., 1986; Bussell, 1989; Baer and 
Beyth, 1990; Jolly and Sanderson, 1995; Glazner et al., 1999; Gall et al., 2005; Nelson et al., 2007; 양석준 외, 2008).

덕구온천 서편에 분포하는 선캠브리아 우백질화강 암을 관입하고 있는 M-80 암맥은 전체적으로 N78 $\mathrm{E} /$ $62^{\circ} \mathrm{SE}$ 의 자세를 가지나, 이 암맥은 관입 이전에 존재 하였던 J-80과 J-150 절리들을 통로로 이용하고 있어 지그재그 형태를 보여준다(Fig. 7). 또한 이 노두에는 기존 $\mathrm{J}-150$ 절리들 $\left(\mathrm{N} 31^{\circ} \mathrm{W} / 78^{\circ} \mathrm{SW}\right.$ 와 $\left.\mathrm{N} 42^{\circ} \mathrm{W} / 73^{\circ} \mathrm{SW}\right)$ 을 이용하여 관입한 분절 사이에 $\mathrm{M}-100$ 에 해당되는 $\mathrm{N} 81^{\circ} \mathrm{W} / 84^{\circ} \mathrm{S}$ 방향의 암맥도 관찰된다(Fig 7B). 이 $\mathrm{M}-100$ 에 해당하는 암맥은 특징적으로 전형적인 강제 형 관입의 증거인 불규칙한 관입경계를 보여준다(Fig. 7D). 그리고 J-80과 J-150이 지그재그 형태로 교차되 는 암맥의 굴곡부에는 기하학적으로 원래 접하고 있 던 부분이 마그마의 관입으로 변위되어 분리된 두 지 점이 관찰된다(Fig. $7 \mathrm{C}$ ). 이 두 지점을 연결한 방향 (Fig. $7 \mathrm{C}$ 의 노란색 화살표)은 $\mathrm{N} 08^{\circ} \mathrm{E}$ 로써, 마그마가
관입 시 실제 지각이 신장된 방향으로 당시의 최소수 평응력 방향을 지시한다. 이 최소수평응력 방향은 강 제형 관입의 특성을 보이는 암맥의 자세 $\mathrm{N} 81^{\circ} \mathrm{W} /$ $84^{\circ} \mathrm{S}$ 와 거의 수직하다. 한편, 관입면의 자세변화에 따 른 관입 폭의 변화를 살펴보면(Fig. 7C), 앞서 구해 진 최소수평응력 방향 $\mathrm{N} 08^{\circ} \mathrm{E}$ 와 고각으로 사교하는 $\mathrm{J}-80$ 암맥구간은 $102 \mathrm{~cm}$ 이며 보다 저각으로 사교하 는 J-150 구간은 두께가 $74 \mathrm{~cm}$ 로 나타났다. 이러한 관입 폭의 크기의 차이는 $\mathrm{N} 80^{\circ} \mathrm{W}, \mathrm{N} 80^{\circ} \mathrm{E}$ 그리고 $\mathrm{N} 30^{\circ} \mathrm{W}$ 의 세 방향의 기존 절리가 연결되어 있었다는 가정 하에 양쪽 지괴를 $\mathrm{N} 10^{\circ} \mathrm{E}$ 방향으로 잡아당겨 벌 어지는 틈의 폭과 비교해 보면 쉽게 이해할 수 있다 (Fig. 7E), 즉, $\mathrm{N} 10^{\circ} \mathrm{E}$ 에 수직한 $\mathrm{N} 80^{\circ} \mathrm{W}$ 방향의 절리 를 따라 가장 넓은 폭의 틈이 만들어지며, 이보다 저 각으로 교차하는 절리일수록 보다 벌어지는 틈이 당 연히 얇을 것이다. 그러나 실제 노두에서는 $\mathrm{N} 80^{\circ} \mathrm{W}$ 방향의 암맥이 다른 방향의 암맥에 비해 얇은 두께를 가지는데(Fig. 7B), 이는 이 방향으로 기존 절리가
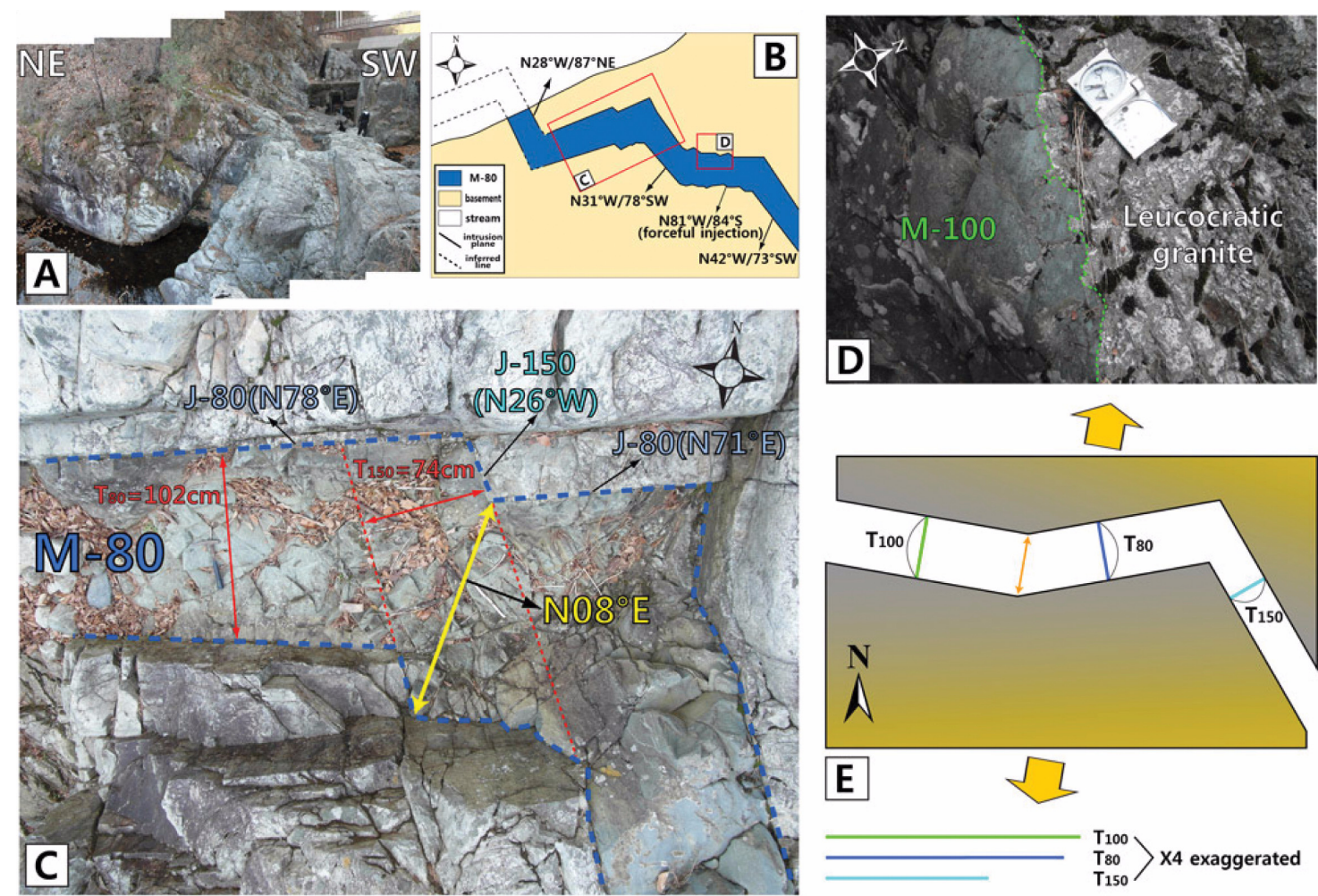

Fig. 7. Outcrop photographs $(A, C)$ and schematic outcrop sketch $(B)$ showing the injection types of $M-80$ and $M-$ 100 (D) as well as the orientation of horizontal minimum stress (yellow arrow). Note the variation of width of dykes about their orientation in the same stress field $(E)$. 


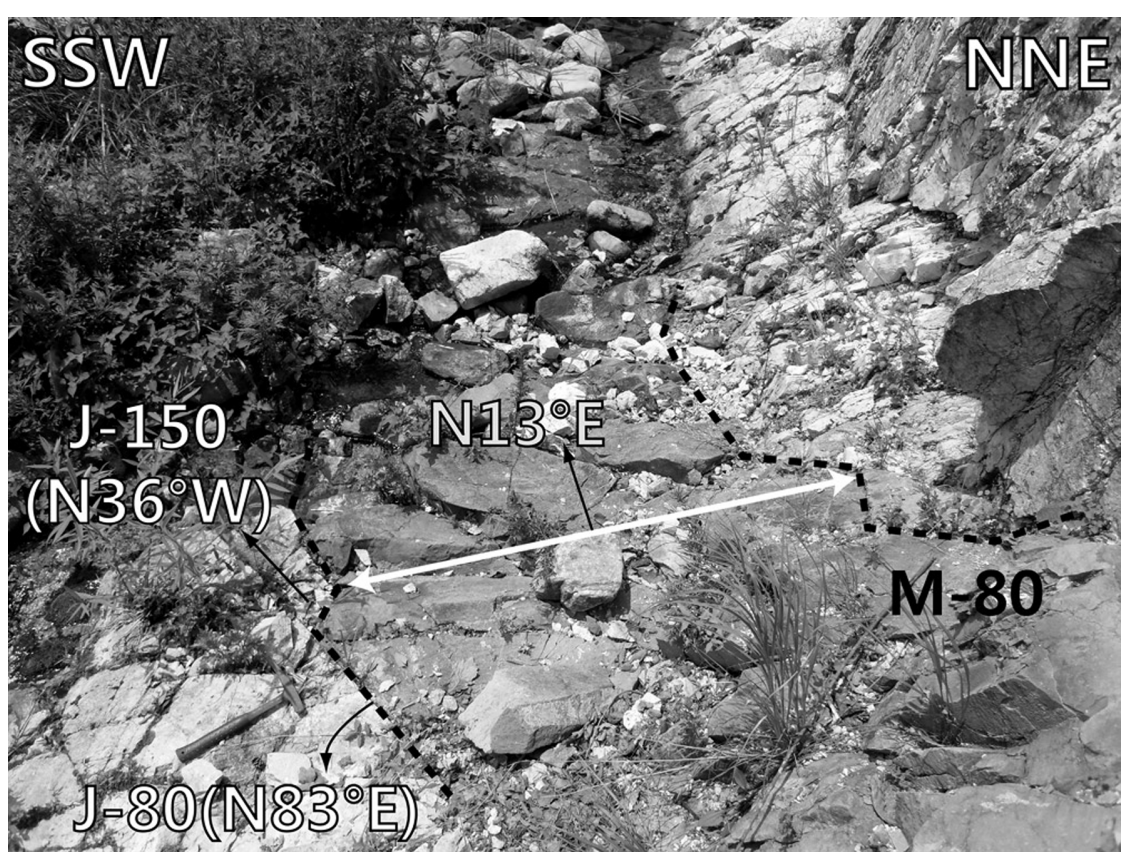

Fig. 8. Outcrop photograph indicating the passive injection of $M-80$ dyke. Its intrusion has been conducted along the preexisting $\mathrm{J}-80$ and $\mathrm{J}-150$ joints. A white arrow indicates the direction of minimum horizontal stress.

존재하지 않아 마그마가 암석 내에 새로운 틈을 만들 면서 강제형으로 주입되었기 때문으로 판단된다. 이 상의 야외 증거들은 $\mathrm{M}-80$ 암맥군이 관입될 당시 약 $\mathrm{N} 10^{\circ} \mathrm{E}$ 방향의 최소수평응력이 작동되었으며, 관입 이 전에 존재하였던 $\mathrm{J}-40, \mathrm{~J}-80, \mathrm{~J}-150$ 등의 절리를 관입 통로로 마그마가 주입되었음을 지시한다. 또한 $\mathrm{N} 10^{\circ} \mathrm{E}$ 방향의 최소수평응력에 수직한 M-100 암맥군은 M80 암맥과 형성 시기는 같으나 마그마 자체 압력에 의해 새로이 단열을 만들면서 주입되었음을 지시해준 다.

연구지역의 기반암 중 최후기에 해당하는 백악기 산성 화산암류를 관입하고 있는 M-80 암맥의 경우도 앞선 경우와 유사하게 J-80과 J-150 방향의 암맥들이 이어지는 지그재그 형태를 보여주고 있어(Fig. 8), 기 존에 존재했던 J-80, J-150 절리를 이용하여 관입되었 음을 알려주고 있다. 또한 관입면의 방향이 변화되는 구간에서 서로 대응되는 지점을 연결하면(Fig. 8의 흰 색 화살표), 이곳도 앞서 얻어진 지각신장 방향과 유 사하게 $\mathrm{N} 13^{\circ} \mathrm{E}$ 방향으로 지각이 신장하여 마그마가 주입되었음을 알 수 있다.

한편 M-10 암맥이 M-80과 $\mathrm{AD}$ 암맥을 절단하는 노두를 자세히 관찰하면, $\mathrm{M}-10$ 의 관입면에 수직한 방
향으로 기존 암맥들이 분리되는 것이 아니라 우수향 으로 관입면과 약 $40^{\circ}$ 로 사교하는 북서-남동 방향으 로 분리되고 있다(Fig. $5 \mathrm{C}$ 와 5E). 이는 M-10 암맥이 관입할 때 이와 수직한 방향의 지각 신장이 발생한 것이 아니라 관입면에 사교하는 최소수평응력이 작동 하여 우수향 전단변위가 동반되었음을 지시하고 있다.

\section{암석기재}

야외에서 방향성에 따라 분류된 4 개의 암맥군(M$10, \mathrm{M}-80, \mathrm{M}-100, \mathrm{AD})$ 들 중 신선하고 대표적인 암 상을 보이는 시료들을 채취하여 현미경 관찰을 실시 하였으며 조직과 구성광물들을 관찰하였다(Fig. 9).

연구지역에서 가장 빈번하게 산출되는 M-80 암맥 은 직사각형의 길쭉한 사장석 결정들로 대부분 구성 되어 있으며, 나머지는 유리질이나 단사휘석 또는 감 람석으로 구성된 인터써틀(intersertal) 조직에서 서브 오피틱(subophitic) 조직을 보여준다(Fig. 9A). M-100 암맥은 휘석 등의 광물 입자가 직사각형의 사장석 사 이에 끼어 있는 입간 조직(inter-granular)에서 서브오 피틱 조직을 보여주고 있는데 M-80 그룹과 매우 유 사한 광물조합과 조직을 보여준다(Fig. 9B). M-100 

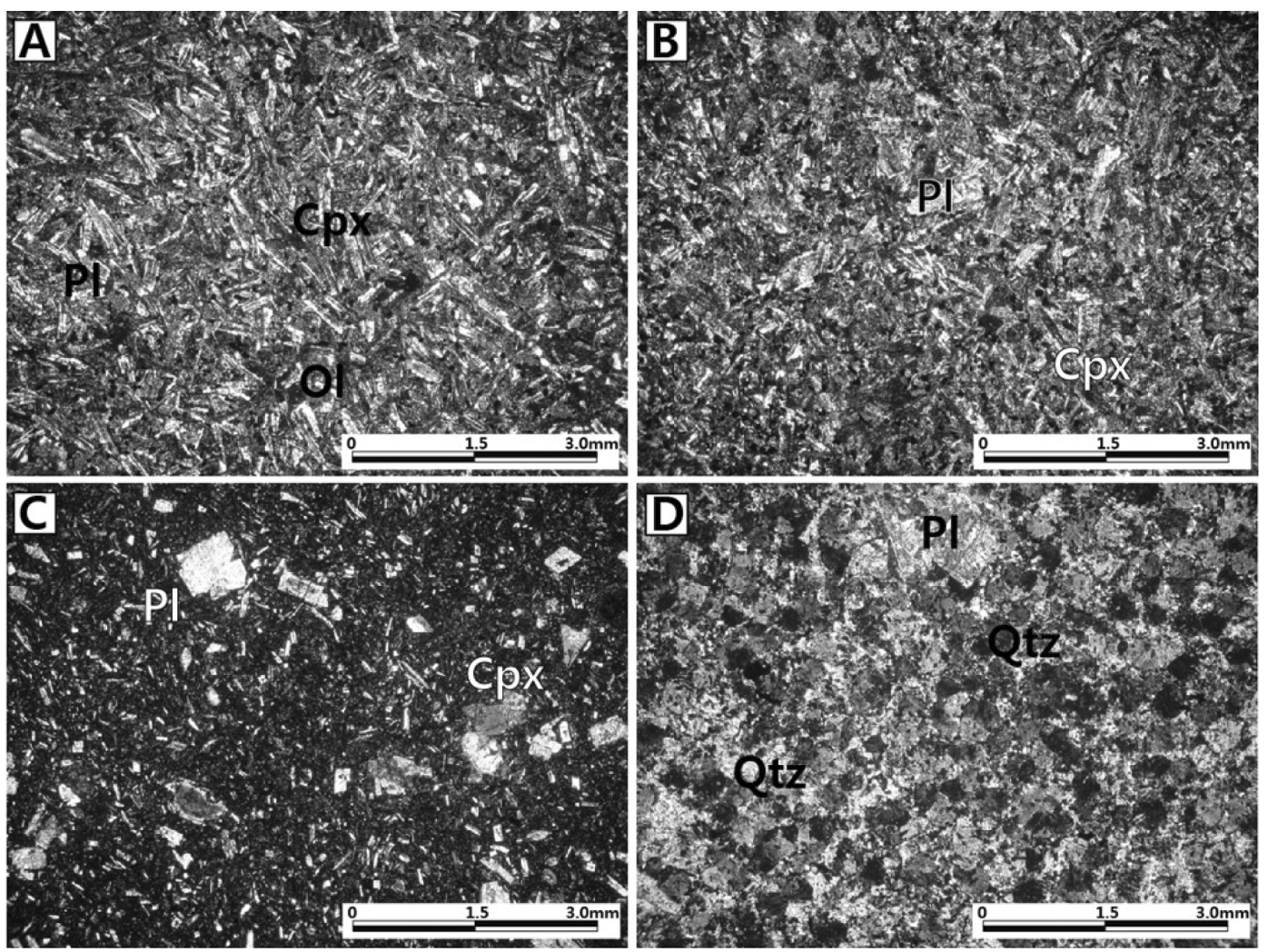

Fig. 9. Thin-section photomicrographs of mafic and felsic dykes (under crossed polars). (A) Photomicrograph of intersertal to subophitic textures in $\mathrm{M}-80$ dyke with minerals of plagioclase (PI), clinopyroxene (Cpx), and olivine (OI). (B) Photomicrograph of inter-granular to subophitic textures in $\mathrm{M}-100$ dyke with minerals of plagioclase $(\mathrm{PI})$, and clinopyroxene (Cpx). (C) Photomicrograph of vitrophyric textures in M-10 dyke with minerals of sieve-texture plagioclase (PI), and clinopyroxene (Cpx). (D) Photomicrograph of porphyritic texture in felsic dyke with minerals of quartz (Qtz), and plagioclase (PI).

암맥은 M-80에 비해 상대적으로 약간 세립의 입자크 기를 보여주는데, 이는 M-100 암맥 시료가 암맥의 가장자리에서 채취된 결과로 판단된다. 암맥 내 광물 입자 크기는 마그마의 조성과는 무관하며 시료채취 지점 또는 암맥의 폭이나 주변 모암과의 온도차 등에 기인한 냉각률의 차이에 주로 좌우될 것이다.

한편, M-10 암맥은 현미경에서 M-80과 M-100과 는 확연한 차이를 보여주는데, 유리질의 기질부에 사 장석과 단사휘석의 반정으로 구성된 유리반정상 (vitrophyric) 조직을 보여준다(Fig. 9C). 특징적으로 현미경 사진의 좌측 아래에 시브(sieve) 조직의 사장 석이 관찰되는데, 화산암에 나타나는 사장석의 시브 조직은 빠른 압력 감소에 따른 온도 상승의 효과로 해석된 바 있다(Nelson and Montana, 1992).

산성 암맥은 $0.5 \mathrm{~mm}$ 내외 크기의 석영과 장석으
로 구성된 기질부에 상대적으로 보다 큰 사장석 반정 으로 구성된 반상조직을 잘 보여준다(Fig. 9D). 기질 부의 석영과 장석은 유리질 석기가 탈유리화되면서 만들어진 구과(spherulite) 조직을 반영하는 것으로 판 단된다.

이상의 암석기재 결과, 연구지역의 암맥들은 크게 염기성(Fig. 9A, 9B, 9C)과 산성 암맥(Fig. 9D)으로 나누어지며, 염기성 암맥군 중 M-80과 M-100은 입 자크기를 제외하면 매우 유사한 광물조합과 조직을 보이는 반면, M-10은 다른 염기성 암맥군들과는 다 른 광물조합과 조직을 보여줌을 알 수 있다.

\section{지화학적 특성}

중성 염기성의 조성을 보이는 M-10, M-80 그리고 


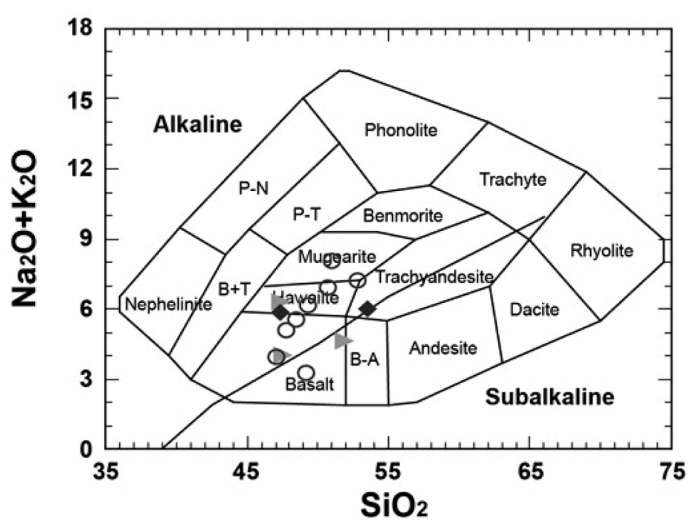

(A)

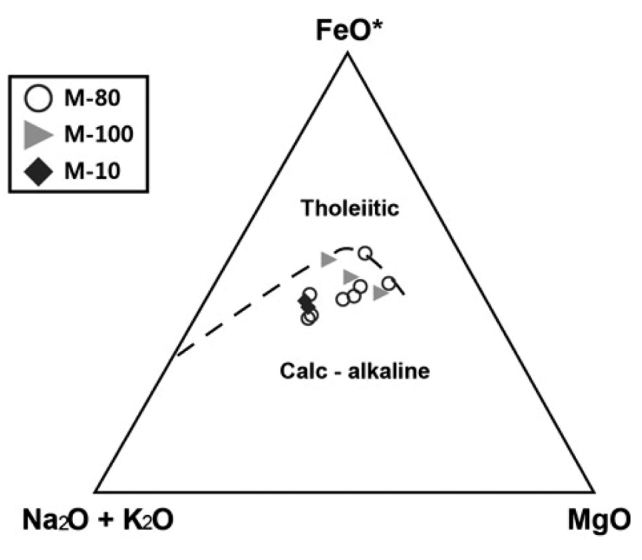

(B)

Fig. 10. (A) Plot of $\mathrm{Na}_{2} \mathrm{O}+\mathrm{K}_{2} \mathrm{O}$ vs. $\mathrm{SiO}_{2}$ for dykes in the study area (after Irvine and Baragar, 1971; Cox et al., 1979). (B) AFM diagram for dykes in the study area (after Irvine and Baragar, 1971).

M-100 암맥군들의 지화학적 특성과 차이를 규명하기 위해, 각 암맥군을 대표할 수 있는 M-80 암맥 시료 8개, M-100 암맥시료 3개, M-10 암맥 시료 2개를 포함한 총 13 개의 시료를 채취하여 부경대학교 공동 실습관의 $\mathrm{X}$-선형광분광분석기 $(\mathrm{XRF})$ 와 기초과학지원 연구원 서울분소의 유도결합플라즈마 원자방출분광분 석기(ICP-AES)와 질량분석기(ICP-MS)를 이용하여 각 각 주성분원소와 미량 및 희토류원소 분석을 실시하 였으며, 전체 철의 양은 $\mathrm{Fe}_{2} \mathrm{O}_{3}$ 로 나타내었다. 분석결 과는 Table 2에 나타내었다.

\section{주성분 원소}

Cox et al. (1979)의 화산암 분류에 따르면, 연구지 역의 중성 염기성 암맥들은 현무암에서 하와이아이트, 뮤기에라니트, 조면안산암 영역에 도시된다(Fig. 10A). TAS(Total alkali vs. $\mathrm{SiO}_{2}$ ) 도표에서 연구지역의 암 맥들은 대부분 알칼리 영역에 도시되며, 일부 시료들 은 비알칼리 영역의 경계에 도시된다(Fig. 10A). 그러 나 암석의 풍화에 따라 알칼리 원소가 부화되는 점을 감안한다면, 연구지역의 화산암류들은 알칼리 계열로 판단하는 것은 주의가 필요할 것으로 판단된다. 그리 고 연구지역의 암맥들이 해양이나 대륙지역의 판내부 열점(hot spot)과 관련된 전형적인 알칼리 계열로 판 단하기에는, 후술할 미량원소나 희토류 원소의 함량 에서 지지되지 않는다. 한편, 이들의 분화계열을 세분 하기 위해 Irvine and Baragar(1971)의 AFM 삼각도 에 주성분 분석치를 도시하면(Fig. 10B), 암맥 시료들
은 모두 칼크-알칼리 계열(calc-alkaline series)에 해 당된다.

\section{미량 및 희토류 원소}

희토류 원소의 함량 변화를 살펴보면(Fig. 11; Table 2), 전체적으로 경희토류 원소(light rare earth elements; LREE)가 중희토류 원소(heavy rare earth elements; HREE)에 비해 상대적으로 부화되어 있다. 암맥군별 그리고 시료별 원소들의 변화패턴을 자세히 살펴보면, M-80과 M-100 암맥군에 속하는 시료들의 희토류 원소의 함량변화 패턴이 전체적으로 매우 유 사함을 알 수 있다. 이 두 암맥군은 암석기재적인 특 징에서도 유사한 조직과 광물조합을 보여주기 때문에 동일한 모 마그마를 기원으로 한 화성활동의 산물일 가능성이 높다. 한편, M-10 암맥군에 속하는 2개 시 료는 모두 중희토류 원소 함량에서 M-80과 M-100과 차이를 보이며 보다 결핍된 특징을 보여준다. 암석기 재적인 특징에서도 이 암맥군이 다른 염기성 암맥군 과 뚜렷한 차이를 보여주고 있어 이러한 희토류 원소 함량의 차이는 M-10 암맥군이 별개의 마그마 활동의 산물일 가능성을 암시한다. 야외에서 관찰된 횡절관 계에서도 M-10 암맥은 M-80과 M-100 암맥들을 절 단하고 있어 시기가 다른 관입사건으로 마그마의 기 원이 달랐을 가능성을 지지한다.

전형적인 중앙해령 현무암에 표준화한 미량원소의 거미도표(Fig. 12)에서도 M-80과 M-100의 암맥들은 콘드라이트에 표준화한 희토류 원소 함량에서 보여준 
Table 2. Major (wt.\%) and trace element abundances (ppm) of the dykes in the study area

\begin{tabular}{|c|c|c|c|c|c|c|c|c|c|c|c|c|c|}
\hline Sample & M80-1 & M80-2 & M80-3 & M80-4 & M80-5 & M80-6 & M80-7 & M80-8 & M100-1 & $\overline{\text { M100-2 }}$ & $\overline{\text { M100-3 }}$ & M10-1 & M10-2 \\
\hline $\mathrm{SiO}_{2}$ & 50.90 & 50.67 & 49.18 & 46.99 & 52.66 & 48.42 & 47.69 & 49.14 & 47.22 & 51.69 & 47.47 & 53.36 & 47.29 \\
\hline $\mathrm{TiO}_{2}$ & 1.42 & 1.24 & 1.58 & 1.96 & 1.72 & 1.75 & 1.78 & 1.53 & 1.91 & 1.56 & 1.51 & 1.11 & 0.99 \\
\hline $\mathrm{Al}_{2} \mathrm{O}_{3}$ & 16.52 & 16.67 & 17.12 & 17.15 & 15.71 & 17.08 & 16.75 & 16.92 & 16.56 & 16.47 & 17.04 & 17.51 & 15.46 \\
\hline $\mathrm{Fe}_{2} \mathrm{O}_{3} *$ & 8.98 & 8.10 & 10.03 & 12.44 & 9.94 & 10.04 & 10.87 & 9.68 & 13.28 & 10.06 & 9.90 & 7.81 & 7.28 \\
\hline $\mathrm{MnO}$ & 0.15 & 0.14 & 0.18 & 0.30 & 0.16 & 0.17 & 0.16 & 0.16 & 0.33 & 0.16 & 0.14 & 0.09 & 0.15 \\
\hline $\mathrm{MgO}$ & 4.62 & 4.16 & 5.69 & 5.44 & 4.07 & 5.96 & 6.16 & 6.41 & 4.49 & 4.88 & 6.71 & 3.26 & 3.36 \\
\hline $\mathrm{CaO}$ & 4.04 & 5.68 & 6.50 & 7.52 & 6.10 & 7.40 & 8.32 & 9.65 & 5.55 & 8.18 & 7.67 & 7.16 & 7.20 \\
\hline $\mathrm{Na}_{2} \mathrm{O}$ & 5.05 & 3.74 & 2.35 & 2.03 & 3.78 & 3.40 & 3.11 & 2.54 & 4.47 & 3.84 & 2.57 & 2.86 & 1.89 \\
\hline $\mathrm{K}_{2} \mathrm{O}$ & 2.78 & 3.02 & 3.69 & 1.95 & 3.24 & 2.03 & 1.90 & 0.79 & 1.70 & 0.78 & 1.49 & 3.04 & 3.84 \\
\hline $\mathrm{P}_{2} \mathrm{O}_{5}$ & 0.50 & 0.45 & 0.55 & 0.54 & 0.42 & 0.52 & 0.52 & 0.45 & 0.53 & 0.58 & 0.42 & 0.32 & 0.30 \\
\hline $\mathrm{LOI}^{* *}$ & 4.95 & 6.03 & 2.74 & 3.36 & 1.81 & 2.77 & 2.73 & 2.61 & 3.61 & 1.43 & 4.84 & 3.31 & 11.88 \\
\hline Total & 99.92 & 99.91 & 99.62 & 99.66 & 99.61 & 99.53 & 99.98 & 99.86 & 99.64 & 99.63 & 99.79 & 99.83 & 99.65 \\
\hline $\mathrm{Ba}$ & 306.5 & 248.4 & 1191 & 256.7 & 410.7 & 210.0 & 390.9 & 122.9 & 396.3 & 522.4 & 161.8 & 1070 & 232.9 \\
\hline $\mathrm{Rb}$ & 82.52 & 166 & 328.9 & 176.9 & 305.3 & 190.9 & 180.4 & 47.89 & 79.93 & 42.53 & 144.4 & 89.70 & 238.8 \\
\hline $\mathrm{Sr}$ & 369.8 & 242.3 & 418.9 & 459.0 & 371.4 & 537.2 & 563.5 & 471.9 & 700.9 & 486.8 & 539.0 & 551.8 & 257.7 \\
\hline $\mathrm{Cs}$ & 1.08 & 6.67 & 8.46 & 7.04 & 4.45 & 5.75 & 10.37 & 7.63 & 1.46 & 3.96 & 4.51 & 6.37 & 13.41 \\
\hline $\mathrm{Ga}$ & 31.85 & 31.63 & 73.57 & 31.94 & 38.98 & 26.20 & 37.20 & 22.71 & 36.10 & 43.78 & 26.20 & 63.58 & 25.21 \\
\hline $\mathrm{Nb}$ & 12.19 & 13.91 & 11.04 & 10.64 & 17.08 & 9.61 & 10.42 & 8.74 & 11.25 & 11.69 & 10.38 & 11.08 & 9.73 \\
\hline Hf & 5.07 & 6.01 & 5.69 & 4.94 & 5.82 & 4.26 & 4.66 & 3.96 & 5.10 & 6.74 & 4.27 & 3.38 & 2.97 \\
\hline $\mathrm{Zr}$ & 205.9 & 235.7 & 243.8 & 187.7 & 205.6 & 180.8 & 184.7 & 152.3 & 203.8 & 292.7 & 163.9 & 119.3 & 107.0 \\
\hline $\mathrm{Y}$ & 29.81 & 33.23 & 32.99 & 33.80 & 36.93 & 29.60 & 31.03 & 27.09 & 39.98 & 33.03 & 25.94 & 26.68 & 23.77 \\
\hline Th & 2.92 & 6.06 & 1.68 & 1.22 & 5.26 & 0.92 & 1.56 & 0.99 & 1.43 & 2.30 & 1.86 & 7.04 & 6.55 \\
\hline $\mathrm{U}$ & 0.75 & 2.06 & 0.44 & 0.39 & 2.30 & 0.81 & 0.39 & 0.22 & 0.35 & 0.56 & 0.55 & 1.52 & 1.83 \\
\hline $\mathrm{La}$ & 23.30 & 32.71 & 24.82 & 23.56 & 28.86 & 21.41 & 24.49 & 18.48 & 26.47 & 28.57 & 20.98 & 26.66 & 22.59 \\
\hline $\mathrm{Ce}$ & 59.12 & 73.96 & 61.06 & 57.50 & 65.31 & 51.19 & 57.65 & 44.48 & 60.66 & 67.11 & 48.71 & 56.44 & 47.67 \\
\hline $\operatorname{Pr}$ & 7.04 & 8.62 & 7.69 & 7.48 & 8.25 & 6.87 & 7.59 & 5.93 & 8.06 & 8.64 & 6.30 & 6.75 & 5.76 \\
\hline $\mathrm{Nd}$ & 38.17 & 45.87 & 41.06 & 39.73 & 43.16 & 36.29 & 40.08 & 31.28 & 42.78 & 45.39 & 33.19 & 35.59 & 30.28 \\
\hline $\mathrm{Sm}$ & 6.71 & 7.40 & 7.60 & 7.44 & 7.82 & 6.85 & 7.42 & 6.02 & 8.06 & 8.02 & 6.01 & 6.07 & 4.94 \\
\hline $\mathrm{Eu}$ & 2.08 & 1.91 & 2.82 & 2.37 & 2.44 & 2.18 & 2.55 & 2.09 & 2.64 & 2.74 & 1.94 & 2.15 & 1.68 \\
\hline $\mathrm{Gd}$ & 7.53 & 8.23 & 8.11 & 8.41 & 8.92 & 7.78 & 8.24 & 7.00 & 9.09 & 8.75 & 6.75 & 6.38 & 5.56 \\
\hline $\mathrm{Tb}$ & 1.02 & 1.12 & 1.11 & 1.17 & 1.27 & 1.08 & 1.14 & 0.98 & 1.25 & 1.20 & 0.93 & 0.87 & 0.75 \\
\hline Dy & 5.50 & 6.05 & 6.04 & 6.42 & 7.09 & 5.93 & 6.35 & 5.61 & 6.55 & 6.69 & 5.23 & 4.47 & 3.99 \\
\hline Ho & 1.04 & 1.16 & 1.16 & 1.23 & 1.36 & 1.13 & 1.20 & 1.07 & 1.25 & 1.27 & 0.99 & 0.85 & 0.77 \\
\hline $\mathrm{Er}$ & 3.15 & 3.54 & 3.56 & 3.73 & 4.19 & 3.40 & 3.67 & 3.27 & 3.84 & 3.95 & 3.00 & 2.65 & 2.43 \\
\hline $\mathrm{Tm}$ & 0.43 & 0.49 & 0.48 & 0.51 & 0.58 & 0.46 & 0.49 & 0.44 & 0.52 & 0.54 & 0.40 & 0.37 & 0.34 \\
\hline $\mathrm{Yb}$ & 2.65 & 3.07 & 2.98 & 3.13 & 3.58 & 2.77 & 3.01 & 2.68 & 3.22 & 3.30 & 2.48 & 2.35 & 2.12 \\
\hline $\mathrm{Lu}$ & 0.41 & 0.47 & 0.47 & 0.48 & 0.55 & 0.42 & 0.47 & 0.41 & 0.50 & 0.51 & 0.37 & 0.37 & 0.34 \\
\hline
\end{tabular}

$\mathrm{Fe}_{2} \mathrm{O}_{3}{ }^{*}$, total iron as $\mathrm{Fe}_{2} \mathrm{O}_{3} ; \mathrm{LOI}^{* *}$, Loss on ignition.

바와 같이 유사한 변화 패턴을 보여준다. 특히 M-80 과 $\mathrm{M}-100$ 시료들과는 달리 $\mathrm{Hf}, \mathrm{Zr}, \mathrm{Sm}, \mathrm{Yb}$ 이 속한 HFSE (High field strength elements)의 함량이 M10 의 두 시료가 가장 낮은 값을 보여준다. 한편, 이번 연구에서 확인된 암맥군들은 전체적으로 불호정성 원 소인 $\mathrm{Sr}, \mathrm{Rb}, \mathrm{Ba}, \mathrm{Th}$ 등이 부화되어 있으며, $\mathrm{Nb}$ 함
량이 상대적으로 결핍된 특징을 보인다. 이는 초기 큰 이온 친석원소(large ion lithophile elements; LILE)의 부화가 상당했음을 의미한다. 이와 같이 경희토류에 비하여 $\mathrm{HFSE}$ 가 결핍되고 강한 LILE 부화를 보이 는 특징은 해양지판의 침강 섭입에 관련된 대륙 연변 부나 도호 등의 지구조 환경과 관련된 암석에서 나타 

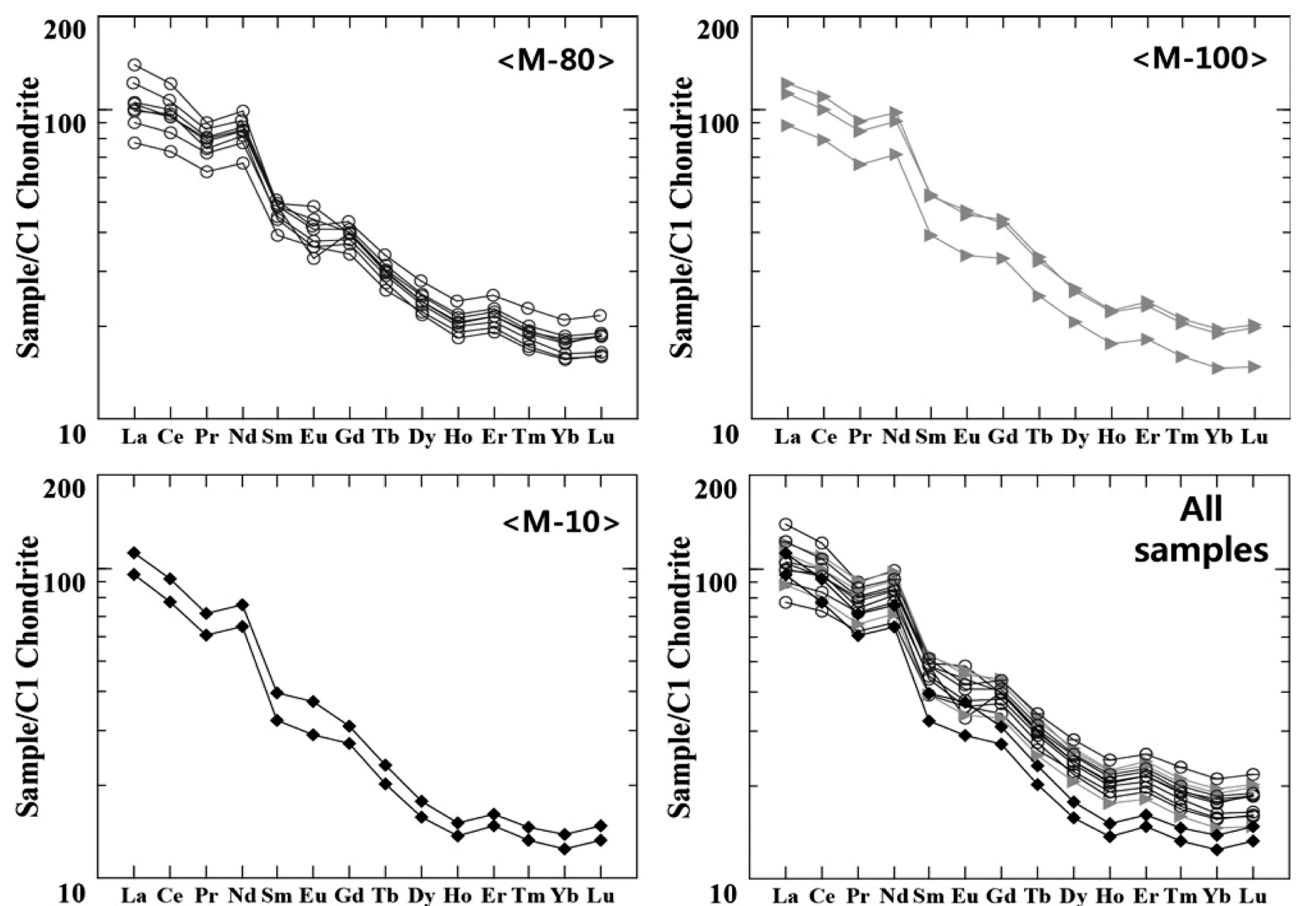

Fig. 11. C1 chondrite normalized REE patterns (normalized data from Sun and McDough, 1989). Symbols are the same as those in Fig. 10.
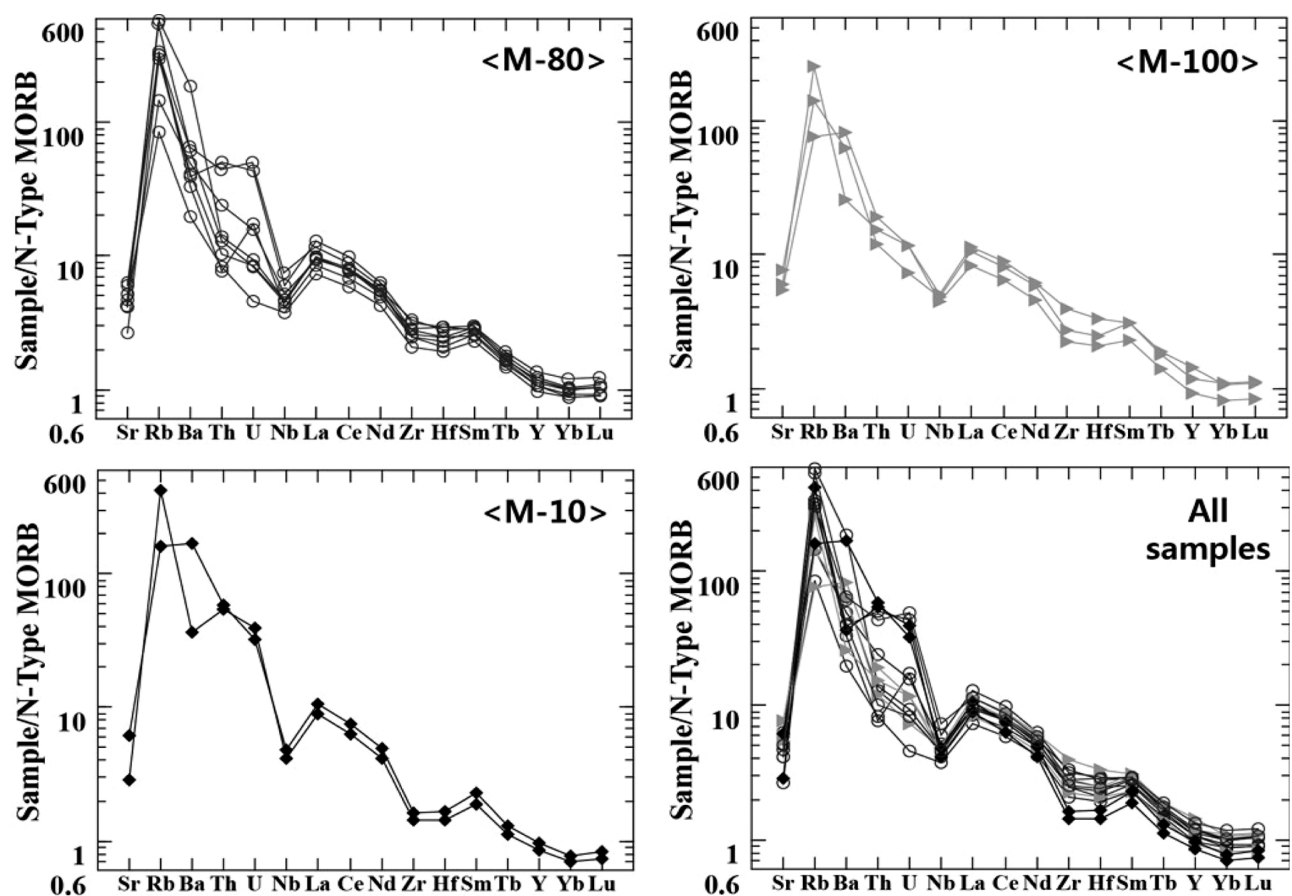

Fig. 12. N-type MORB normalized spider diagram for trace element (normalized data from Sun and McDough, 1989). Symbols are the same as those in Fig. 10. 
나는 것으로 알려져 있다(Wilson, 1989; Pearce et al., 2000). 따라서 연구지역의 암맥군들은 해양지각의 섭 입과 관련된 화성활동의 산물인 것으로 판단된다.

\section{토 의}

앞서 언급한 바와 같이 암맥의 정치기구는 크게 강 제형과 수동형의 두 가지로 나눌 수 있으며, 암맥의 기하는 관입 이전에 존재하는 기존 단열계의 기하학 적 특성에 따라 매우 달라질 수 있다. 마그마압력에 의해 새로이 생성된 단열을 따라 마그마가 주입되는 전형적인 강제형 관입은 관입면에 수직한 방향을 당 시의 지각신장방향으로 해석할 수 있으나, 기존 단열 들을 따라 마그마가 관입하면 강제형과 수동형 모두 암맥의 기하에 대한 세밀한 해석을 통하여 당시의 지 각신장방향을 결정하여야한다. 연구지역에서 염기성 암맥군은 방향성 및 횡절관계에 따라 $\mathrm{M}-10, \mathrm{M}-80$, $\mathrm{M}-100$ 의 세 그룹으로 나눌 수 있으며, 정치기구에 따라 M-10과 $\mathrm{M}-80$ 은 기존의 절리를 통로로 하여 관 입한 특징을 보여주는 반면, M-100은 대부분 마그마 압력에 의한 수압단열의 결과로 만들어져 관입면이 울퉁불퉁한 특징을 보여준다. M-80은 대부분 암맥 관 입 이전에 생성되어 있던 J-80, J-40, J-150 절리군을 통로로 이용하였지만, 덕구 온천 옆 계곡 노두에서는 기존 절리를 이용하여 관입한 양상과 기존 절리가 존 재하지 않는 구간에서는 새로이 만들어진 단열을 따 라 주입된 강제형 관입의 특징을 동시에 보여주기도 한다(Fig. 7). 여기서 주목할 점은 강제형 관입부의 관입방향은 M-100 암맥군의 주 방향과 유사한 동남 동-서북서 방향이며, 이 방향은 지그재그 형태로 관입 을 하는 M-80 암맥에서 측정된 최소수평응력 방향인 북북동-남남서 방향에 수직한다. 이는 암맥이 수압파 쇄를 일으킨 강제형 관입일 경우에는 평균 관입방향 에 수직한 방향이 지각신장방향으로 해석할 수 있으 나, 기존 절리를 이용하여 관입한 경우에는 암맥의 관입방향에 수직한 방향을 지각신장 방향으로 해석하 면 오류가 발생할 수 있음을 지시해준다. 따라서 야 외에서 암맥을 이용한 지각신장방향을 결정할 시에 수압파쇄를 동반하는 강제형 관입이라면 평균관입방 향에 수직한 방향으로 해석할 수 있으나 기존절리를 통로로 이용한 관입의 경우에는 관입면의 기하, 특히 지그재그 형태로 관입면의 방향이 변화되는 곳의 기 하를 보다 면밀히 기재 - 분석하여야 할 것이다.
야외에서 확인된 횡절관계에 의해 연구지역 절리군 및 암맥군들 간의 상대연령은 $<\mathrm{J}-40, \mathrm{~J}-80, \mathrm{~J}-150>\rightarrow$ $<\mathrm{M}-80$ (M-100) $>\rightarrow<\mathrm{AD}>\rightarrow<\mathrm{J}-10>\rightarrow<\mathrm{M}-10>\rightarrow$ $<\mathrm{F}-340 \mathrm{R}>$ 순서로 분석되었다. 그러나 암맥의 정치와 단열의 발달 시기를 정확히 알고 이와 관련된 광역적 인 고응력사를 해석하기 위해서는 암맥의 절대연령을 밝히는 작업이 필요하다. 이번 연구에서 암맥들의 절 대연령을 비록 구하지는 못하였으나, 최근 한반도 동 남부 일원에서 얻어진 기존 암맥군들의 야외기재 및 절대연령 그리고 동아시아 일원 지구조 발달사 해석 결과를 연구지역 암맥 및 단열군과 대비하여 해석하 면 다음과 같다.

한반도 동남부 경주-감포 지역과 거제도 지역에는 북북동-남남서 방향의 인장력 환경에서 수동형으로 관 입한 서북서-동남동 방향의 염기성 암맥군이 분포하 고 있음이 보고되어 있다(김종선 외, 2005; 손문 외, 2007a). 이들에 대한 K-Ar과 $\mathrm{Ar}-\mathrm{Ar}$ 연대측정 결과, 그 관입시기가 64 52 Ma인 것으로 밝혀졌다. 이들 암맥군은 연구지역의 M-80(M-100)과 기하 및 형성 응력장에서 대비된다. 제3기 초인 64 52 Ma에는 동 아시아 연변에는 쿨라판을 뒤따르며 북상하던 태평양 판이 북북서 방향으로 유라시아판 아래로 사교 섭입 함으로써 광역적인 좌수향 전단응력장이 작동하였던 것으로 알려져 있다(Hall, 2002; 손문 외, 2007b). 따 라서 M-80(M-100) 암맥군은 북북서 방향의 광역적인 좌수향 전단응력으로 육지에 유도된 북북동-남남서 방 향의 인장응력 하에서 기존 단열들 중 주로 이와 수 직에 가까운 단열들을 선택적으로 관입 통로로 이용 하여 수동형으로 관입하였으며, 일부는 마그마 압력 에 의한 수압단열을 통해 새로이 만들어진 서북서 방 향의 단열을 따라 강제형으로 관입한 것으로 판단된 다.

주로 기존 단열군인 $\mathrm{J}-10$ 을 관입통로로 관입한 $\mathrm{M}-$ 10 은 M-80과 산성질 암맥들을 절단하고 있다. 이들 의 관입으로 변위된 기존 암맥들의 기하학적 특징은 이들 암맥이 관입할 시기의 지각신장방향이 관입면에 수직이 아니라 우수향 전단변위가 동반된 북서-남동 방향임을 지시한다(Fig. $5 \mathrm{C}$ 와 E). 연구지역외에도 보 다 남쪽의 한반도 동남부에는 도처에 북북동 방향의 염기성 암맥군이 흔히 관찰되는데, 이들에 대한 $\mathrm{Ar}-$ $\mathrm{Ar}$ 전암연대는 51 44 Ma로 나타났으며(김종선 외, 2005; 손문 외, 2007a) 연구지역과 인접한 울진군 기 성면 용당 지역에 분포하는 남북 내지 북북동 방향의 
중성 암맥의 $\mathrm{K}-\mathrm{Ar}$ 전암연대는 이보다 젊은 약 35 28 Ma의 연령을 보여준다(양석준 외, 2010). 이 시기는 고제3기 에오세와 올리고세에 해당되는 시기 로 인도와 유라시아 대륙의 충돌이후 동아시아 대륙 이 동쪽으로 밀려나고(Tapponnier and Molnar, 1976; 김인수, 1992; Fournier et al, 2004) 해구의 퇴각이 발생하여 동아시아에 서북서-동남동 방향의 인장력이 작동된 시기로 해석되고 있다(손문 외, 2007a, 2007b). 이번 연구에서 해석된 M-10 암맥군이 관입할 당시의 응력장은 북서-남동 방향으로 일부 차이를 보이기는 하나, 이들 암맥의 기하와 상대연령을 근거할 때 관 입 시기는 에오세 올리고세일 가능성이 높다.

한편, 약 $25 \mathrm{Ma}$ 경부터 중기 마이오세 까지 일본 열도가 동아시아에서 분리되면서 동해가 남북 내지 북북서-남남동 방향으로 활발히 확장되어 한반도 동 해안에는 북북서 방향의 우수향 전단력이 발생하고 이에 따라 북서-남동 방향의 인장력이 유되되어 당겨 열림형(pull-apart) 분지들이 확장한 것으로 알려져 있 다(손문과 김인수, 1994; 손문, 1998; Son et al., 2000,2005 ; 손문 외, 2007b). 연구지역 단열들 중 북 서 내지 북북서 방향의 J-150 단열군 중 일부는 특 징적으로 최후기에 우수향 주향이동단층으로 재활되 어 기존 암맥과 단열들을 우수향으로 변위시키고 있 다(Fig. 5와 6). 따라서 이번 연구에서 F-340R로 구 분된 최후기 우수향 주향이동단층들은 동해가 활발히 확장하던 시기인 마이오세의 고응력장인 북북동 방향 의 최대주응력 하에서 기존 단열들 중 주로 J-150 단열들이 선택적으로 재활된 것으로 해석된다.

\section{결 론}

한반도 동부 울진군 죽변-부구 지역에 분포하는 체 계적인 방향성으로 보이는 암맥과 절리들의 자세를 측정한 결과, 암맥들은 세 개의 중성 염기성 암맥군 (M-10, M-80, M-100)과 한 개의 산성 암맥군(AD) 그리고 절리들은 4 개의 절리군 $(\mathrm{J}-10, \mathrm{~J}-40, \mathrm{~J}-80, \mathrm{~J}-$ 150)으로 분류할 수 있었다. 또한 야외에서 J-150에 속하는 절리들 중 일부가 최후기에 우수향 주향이동 단층으로 재활된 F-340R 단층군이 존재하고 있음이 확인된다. 야외에서 M-100 암맥군과 다른 암맥군 및 절리군 간의 횡절관계를 확인하지 못하였으나, 그 외 다른 암맥군과 절리군의 야외 산상과 횡절관계 그리 고 암맥들의 경하관찰을 통한 암석기재와 지화학 자
료 등을 종합하면, M-80과 M-100 암맥군은 동일한 응력장 하에서 같은 모 마그마로부터 유래되었으며, $\mathrm{M}-80$ 은 기존 단열들을 통로로 관입을 한 반면, M100 암맥군은 주로 마그마압력에 의한 수압파쇄단열 을 통로로 하는 강제형 관입을 한 것으로 판단된다. 또한 이번 연구에서 분류된 암맥군과 단열군들은 < $<\mathrm{J}$ $40, \mathrm{~J}-80, \mathrm{~J}-150>\rightarrow<\mathrm{M}-80$ (M-100) $>\rightarrow<\mathrm{AD}>\rightarrow$ $<\mathrm{J}-10>\rightarrow<\mathrm{M}-10>\rightarrow<\mathrm{F}-340 \mathrm{R}>$ 순서로 형성된 것 으로 결론지어진다. 그리고 암맥들의 기하학적 특징 을 분석한 결과, $\mathrm{M}-80$ 과 $\mathrm{M}-100$ 암맥군은 $\mathrm{N} 10^{\circ} \mathrm{E}$ 의 최소수평응력장 하에서 그리고 M-10 암맥군은 북서남동 방향의 최소수평응력장 하에서 관입된 것으로 판단된다. 한편 기존 절대연령 및 지구조 발달사 해 석 연구결과들과 이번 연구결과를 종합적으로 분석하 면, M-80(M-100) 암맥군은 64 52 Ma 경 태평양판 이 북북서 방향으로 사교 섭입함으로써 발생한 광역 적인 좌수향 전단응력장의 결과이며, $\mathrm{M}-10$ 은 제 3 기 에오세 올리고세에 인도와 유라시아 대륙의 충돌한 이후 동아시아 대륙의 동진과 해구의 퇴각과 밀접한 관련이 있을 것으로 추정된다. 또한 이번 연구에서 최후기 단열로 분류된 F-340R은 동해가 활발히 확장 하던 시기인 마이오세의 한반도 동해안의 지각변형과 밀접히 관련되는 것으로 해석된다.

\section{사 사}

심사과정에서 유익한 조언을 주신 부경대 김영석 교수님과 KIGAM 진광민 연구원께 감사드립니다. 이 연구는 대한민국 교육과학기술부의 원자력기술개발사 업, “원전부지 인근 신기지구조 및 해안단구 검증조 사” 과제로 수행되었음을 밝히며, 이에 감사드립니다.

\section{참고문헌}

강지훈, 이덕선, 정원석, 나기창, 2006 , 경상북도 울진군 북 면 일대의 지질구조(요약문). 대한지질학회 추계학술 발 표회 초록집, 123 .

김인수, 1992 , 새로운 동해의 성인모델과 양산단층계의 주 향이동운동. 지질학회지, 28, 84-109.

김종선, 손문, 김진섭, 김정민, 2005 , 한반도 남동부 제 3 기 암맥군과 화산암류의 ${ }^{40} \mathrm{Ar}{ }^{39} \mathrm{Ar}$ 연대. 암석학회지, 14,93 107.

김진섭, 손문, 김종선, 김인수, 2002 , 한반도 남동부 제 3 기 암맥군과 지구조적 중요성. 암석학회지, 11, 169-181. 손문, 김인수, 1994 , 울산군 강동면 제 3 기 정자분지의 지질 
구조와 분지발달. 자원환경지질, 27, 65-80.

손문, 김종선, 정혜윤, 이융희, 김인수, $2007 \mathrm{~b}$, 한반도 동남 부 신생대 지각변형의 주요 특징과 지구조적 의의. 한국 석유지질학회지, $13,1-16$.

손문, 김종선, 황병훈, 이인현, 김정민, 송철우, 김인수, $2007 \mathrm{a}$, 거제도 동부에 분포하는 고제 3 기 암맥군: 절대연 대와 지구조적 의미. 암석학회지, $16,82-99$.

손문, 1998 , 한반도 동남부 제 3 기 마이오세 분지의 형성과 발달: 구조지질학 및 고자기학적 고찰. 부산대학교 이학 박사 학위논문, $233 \mathrm{p}$

안성호, 김종선, 조형성, 송철우, 손문, 류충렬, 김인수, 2010 , 한반도 남부 원생대 산청회장암체 내 암맥군의 분 류와 상대연령. 지질학회지, 46, 13-30.

양석준, 박승현, 김정빈, 송교영, 김영석, 2010, 울진군 용당 지역의 단열 발달사와 암맥의 관입 특성. 지질학회지, 46 , 233-251.

양석준, 진광민, 김영석, 2008 , 거제도 지역 암맥의 관입형 태와 변형사로부터 도출된 고응력장의 변화. 지질학회지, 44, 747-764.

이기화, 2010 , 한반도의 지진활동과 지각구조. 지구물리와 물리탐사, 13, 256-267.

이종혁, 김용준, 최병열, 1993 , 한국지질도 $(1: 50,000)$ 죽변임원진 도폭 및 설명서. 한국자원연구소, $20 \mathrm{p}$.

정창식, 길영우, 김정민, 정연중, 임창복, 2004 , 영남육괴 북 동부 죽변 지역 선캠브리아기 기반암의 지구화학적 특징. 지질학회지, 40, 481-499.

정창식, 이희권, 장병욱, 김정민, 이석훈, 임창복, 이종대, 김 연중, 2001 , 경북 울진지역 단층대 단층암에 대한 연대 측정. 지질학회지, $37,375-392$

Anderson, E.M., 1951, The dynamics of faulting and dyke formation with application to Britain. Edinburgh \& London, Oliver and Boyd.

Baer, G. and Beyth, M., 1990, A mechanism of dyke segmentation in fractured host rock. In: Parker, A.J., Rickwood, P.C., Tucker, D.H. (Eds.), Mafic Dykes and Emplacement Mechanisms, A.A. Balkema, Rotterdam, 311.

Bahar, I. and Girod, M., 1983, Controle structural du volcanisme Indonesien (Sumatra, Java-Ball); application et critique de la methode de Nakamura. Bull. Soc. Geol. Fr., 25, 609-614.

Best, M.G., 1988, Early Miocene change in direction of least principal stress, southwestern United States - conflicting inferences from dikes and metamorphic coredetachment fault terranes. Tectonics, 7, 249-259.

Borradaile, G.J., 2001, Paleomagnetic vectors and tilted dikes. Tectonophysics, 333, 417-426.

Bussell, M.A., 1989, A simple method for the determination of the dilation direction of intrusive sheets. J. Struct. Geol., 11, 679-687.

Cox, K.G., Bell, J.D. and Pankhurst, R.J., 1979, The interpretation of igneous rocks. George Allen \& Unwin, London, 450p.
Delaney, P.T., Pollard, D.D., Ziony, J.I. and McKee, E.H., 1986, Field relationship between dikes and joints: Emsplacement process and paleostress. J. Geophys. Res., 91, 4920-4938.

Esher, A., Jack, S. and Watterson, J., 1976, Tectonics of the North Atlantic dyke swarm. Phil. Trans. Roy. Soc. Lond., A, 280, 529-539.

Fournier, M., Jolivet, L., Davy, P. and Thoma, J.-C., 2004, Backarc extension and collision: an experimental approach to the tectonics of Asia. Geophys. J. Int., 157, 871-889.

Gall, L.B., Tshoso, G., Dyment, J., Kampunzu, A.B., Jourdan, F., Feraud, G., Bertrand, H., Aubourg, C. and Vetel, W., 2005, The Okavango giant mafic dyke swarm (NE Botswana): its structural significance within the Karoo Large Igneous Province. J. Struct. Geol., 27, 2234-2255.

Gautneb, H. 1988, Structure, age and formation of dykes on the island of Smola, Central Norway. Norsk Geografisk Tidsskrift, 68, 275-288.

Glazner, A.F., Bartley, J.M. and Carl, B.S., 1999, Oblique opening and noncoaxial emplacement of the Jurassic independence dike swarm, California. J. Struct. Geol., 21, 1275-1283.

Hall, R., 2002, Cenozoic geological and plate tectonic evolution of SE Asia and the SW Pacific: computer-based reconstructions, model and animations. J. Asian. Earth. Sci., 20, 353-431.

Hutton, D.H.W., 1988, Granite emplacement mechanisms and tectonic controls: inferences from deformational studies. Trans. Earth. Sci., 79, 245-255.

Irvine, T.N. and Baragar, W.R.A., 1971, A guide to the common volcanic rocks. Can. J. Earth. Sci., 8, 532-548.

Jolly, R.J.H. and Sanderson, D.J., 1995, Variation in the form and distribution of dykes in the Mull swarm, Scotland. J. Struct. Geol., 17, 1543-1557.

Khan, T., Murata, M., Karim, T., Zafar, M., Ozawa, H. and Rehman, H., 2006, A Cretaceous dike swarm provides evidence of a spreading axis in the back-arc basin of the Kohistan paleo-island arc, northwestern Himalaya, Pakistan. J. Asian. Earth. Sci., 29, 350-360.

Lee, K. and Yang, W.S., 2006, Historical seismicity of Korea. Bull. Seism. Soc. Am., 96, 846-855.

Mayborn, K.R. and Lesher, C.E., 2004, Paleoproterozoic mafic dike swarms of northeast Laurentia: products of plumes or ambient mantle? Earth. Planet. Sci. Lett., 225, 305-317.

Nelson, S.T. and Montana, A., 1992, Sieve-textured plagioclase in volcanic rocks produced by rapid decompression. Am. Mineral., 77, 1242-1249.

Nelson, E.J., Chipperfield, S.T., Hillis, R.R., Gilbert, J., McGowen, J. and Mildren, S.D., 2007, The relationship between closure pressures from fluid injection tests and the minimum principal stress in strong rocks. Int. J. 
Rock. Mech. Min. Sci., 44, 787-801.

Pearce, J., Kempton, P. and Nowell, G., 2000, The origin of HFSE anomalies in subduction zone magmas: evidence from Hf-Nd isotope and element covariations. Goldschmidt 2000, September 3rd-8th, 2000, Oxford, UK. Journal of Conference Abstracts, 5, 775.

Price, N.J. and Cosgrove, J.W., 1990, Analysis of geological structures. Cambridge University Press, Cambridge, 64p.

Raymond, L.A., 1995, Petrology. The McGraw-Hill Company, New York, 125-126.

Son, M., Kim, I.-S. and Sohn, Y.K., 2005, Evolution of the Miocene Waup Basin, SE Korea, in response to dextral shear along the southeastern margin of the East Sea (Sea of Japan). J. Asian. Earth. Sci., 25, 529-544.

Son, M., Seo, H.-J. and Kim, I.-S., 2000, Geological Structures and Evolution of the Miocene Eoil Basin, Southeastern Korea. Geosci. J., 4, 73-88.

Speight, J.M. and Mitchell, J.G., 1979, The Permo-Carboniferous dyke-swarm of northern Argyll and its bearing on dextral displacements on the Great Glen Fault. J. Geol. Soc. Lond., 136, 3-11.

Sun, S.S. and McDough, W.F., 1989, Chemical and isotopic systematics of oceanic basalts: implications for mantle composition and process. In: Saunders, A.D. and M.J. (eds.), Magmatism in ocean basins. Geol. Soc. London. spec. Pub., 42, 313-345.

Tapponnier, P. and Molnar, P., 1976, Slip-line field theory and large scale continental tectonics. Nature, 264, 319324.

Tokarski, A.K., 1990, Dyke swarms as stress indicators: Two constrains. In: Parker, A.J., Rickwood, P.C., Tucker, D.H. (Eds.), Mafic Dykes and Emplacement Mechanisms. A.A. Balkema, Rotterdam, 101-104.

Valentine, G.A. and Krogh, K.E.C., 2006, Emplacement of shallow dikes and sills beneath a small basaltic volcanic center - The role of pre-existing structure (Paiute Ridge, southern Nevada, USA). Earth. Planet. Sci. Lett., 246, 217-230.

Wilson, M., 1989, Igneous petrogenesis a global tectonic approach. Chapman and Hall, London, 466p.

2011년 10월 3일 접수

2011년 10월 13일 심사개시

2011년 12월 13일 채택 